\title{
Integrated ecological monitoring in Wales: the Glastir Monitoring and Evaluation Programme field survey
}

\author{
Claire M. Wood ${ }^{1}$, Jamie Alison ${ }^{2}$, Marc S. Botham ${ }^{3}$, Annette Burden ${ }^{2}$, François Edwards ${ }^{3}$, \\ R. Angus Garbutt ${ }^{2}$, Paul B. L. George ${ }^{4}$, Peter A. Henrys ${ }^{1}$, Russel Hobson ${ }^{5}$, Susan Jarvis ${ }^{1}$, \\ Patrick Keenan $^{1}$, Aidan M. Keith ${ }^{1}$, Inma Lebron ${ }^{2}$, Lindsay C. Maskell ${ }^{1}$, Lisa R. Norton ${ }^{1}$, \\ David A. Robinson ${ }^{2}$, Fiona M. Seaton ${ }^{1}$, Peter Scarlett ${ }^{3}$, Gavin M. Siriwardena ${ }^{6}$, James Skates ${ }^{7}$, \\ Simon M. Smart ${ }^{1}$, Bronwen Williams ${ }^{2}$, and Bridget A. Emmett ${ }^{2}$ \\ ${ }^{1}$ UK Centre for Ecology \& Hydrology, Lancaster Environment Centre, \\ Library Avenue, Bailrigg, Lancaster, LA1 4AP, UK \\ ${ }^{2}$ UK Centre for Ecology \& Hydrology, Environment Centre Wales, \\ Deiniol Road, Bangor,Gwynedd, LL57 2UW, UK \\ ${ }^{3}$ UK Centre for Ecology \& Hydrology, Maclean Building, Benson Lane, \\ Crowmarsh Gifford, Wallingford, Oxfordshire, OX10 8BB, UK \\ ${ }^{4}$ School of Natural Sciences, Bangor University, Deiniol Road, Bangor, Gwynedd, LL57 2UW, UK \\ ${ }^{5}$ Butterfly Conservation, Manor Yard, East Lulworth, Wareham, Dorset, BH20 5QP, UK \\ ${ }^{6}$ British Trust for Ornithology, BTO, The Nunnery, Thetford, Norfolk, IP24 2PU, UK \\ ${ }^{7}$ Welsh Government, Sarn Mynach, Llandudno Junction, Conwy, UK \\ Correspondence: Claire M. Wood (clamw@ceh.ac.uk)
}

Received: 25 February 2021 - Discussion started: 26 March 2021

Revised: 9 July 2021 - Accepted: 12 July 2021 - Published: 26 August 2021

\begin{abstract}
The Glastir Monitoring and Evaluation Programme (GMEP) ran from 2013 until 2016 and was probably the most comprehensive programme of ecological study ever undertaken at a national scale in Wales. The programme aimed to (1) set up an evaluation of the environmental effects of the Glastir agri-environment scheme and (2) quantify environmental status and trends across the wider countryside of Wales. The focus was on outcomes for climate change mitigation, biodiversity, soil and water quality, woodland expansion, and cultural landscapes. As such, GMEP included a large field-survey component, collecting data on a range of elements including vegetation, land cover and use, soils, freshwaters, birds, and insect pollinators from up to three-hundred $1 \mathrm{~km}$ survey squares throughout Wales. The field survey capitalised upon the UK Centre for Ecology \& Hydrology (UKCEH) Countryside Survey of Great Britain, which has provided an extensive set of repeated, standardised ecological measurements since 1978. The design of both GMEP and the UKCEH Countryside Survey involved stratified-random sampling of squares from a $1 \mathrm{~km}$ grid, ensuring proportional representation from land classes with distinct climate, geology and physical geography. Data were collected from different land cover types and landscape features by trained professional surveyors, following standardised and published protocols. Thus, GMEP was designed so that surveys could be repeated at regular intervals to monitor the Welsh environment, including the impacts of agri-environment interventions. One such repeat survey is scheduled for 2021 under the Environment and Rural Affairs Monitoring \& Modelling Programme (ERAMMP).

Data from GMEP have been used to address many applied policy questions, but there is major potential for further analyses. The precise locations of data collection are not publicly available, largely for reasons of landowner confidentiality. However, the wide variety of available datasets can be (1) analysed at coarse spatial resolutions and (2) linked to each other based on square-level and plot-level identifiers, allowing exploration of relationships, trade-offs and synergies.

This paper describes the key sets of raw data arising from the field survey at co-located sites (2013 to 2016). Data from each of these survey elements are available with the following digital object identifiers (DOIs):
\end{abstract}


Landscape features (Maskell et al., 2020a-c), https://doi.org/10.5285/ 82c63533-529e-47b9-8e78-51b27028cc7f, https://doi.org/10.5285/9f8d9cc6-b552-4c8b-af09-e92743cdd3de, https://doi.org/10.5285/f481c6bf-5774-4df8-8776-c4d7bf059d40; Vegetation plots (Smart et al., 2020), https://doi.org/10.5285/71d3619c-4439-4c9e-84dc-3ca873d7f5cc; Topsoil physico-chemical properties (Robinson et al., 2019), https://doi.org/10.5285/0fa51dc6-1537-4ad6-9d06-e476c137ed09; Topsoil mesofauna (Keith et al., 2019), https://doi.org/10.5285/1c5cf317-2f03-4fef-b060-9eccbb4d9c21; Topsoil particle size distribution (Lebron et al., 2020), https://doi.org/10.5285/d6c3cc3c-a7b7-48b2-9e61-d07454639656; Headwater stream quality metrics (Scarlett et al., 2020a), https://doi.org/10.5285/ e305fa80-3d38-4576-beef-f6546fad5d45; Pond quality metrics (Scarlett et al., 2020b), https://doi.org/10. 5285/687b38d3-2278-41a0-9317-2c7595d6b882; Insect pollinator and flower data (Botham et al., 2020), https://doi.org/10.5285/3c8f4e46-bf6c-4ea1-9340-571fede26ee8; and Bird counts (Siriwardena et al., 2020), https://doi.org/10.5285/31da0a94-62be-47b3-b76e-4bdef3037360.

\section{Introduction}

The Welsh Government initiated the Glastir Monitoring and Evaluation Programme (GMEP) in 2013 to evaluate the environmental effects of the Glastir agri-environment scheme at a national scale but also to monitor the wider countryside of Wales (Emmett et al., 2015) in the longer term. In Wales, funding from agri-environment schemes (AESs) has been available since the early 1990s including Environmentally Sensitive Areas (ESAs), the Habitat Scheme, Woodland Grant Scheme, Farm and Conservation grant scheme, Tir Cymen, Tir Cynnal, Tir Gofal and most recently Glastir. Currently, the Glastir scheme is the main method that the Welsh Government pays for environmental goods and services (Emmett and GMEP team, 2014). The primary aim of GMEP monitoring was to collect evidence for the effectiveness of bundles of management interventions in delivering outcomes of interest related to climate change mitigation, biodiversity, soil and water quality, woodland expansion, and cultural landscapes. Two additional objectives for reporting were added by the auditor general for Wales in 2014: (1) to increase the level of investment in measures for climate change adaptation, with the aim of building greater resilience to ongoing climate change into both farm and forest businesses and the wider Welsh economy, and (2) to use agri-environmental investment in a way that contributes towards farm and forest business profitability and the wider sustainability of the rural economy (Emmett and GMEP team, 2017).

The monitoring also collected evidence to quantify the status and trends in the environment in general and contributed to the The Second State of Natural Resources Report (SoNaRR2020) (Natural Resources Wales, 2020). The data collected may be analysed in order to identify how drivers of change, such as land use, climate and pollution affect the Welsh environment, beyond Glastir interventions (Emmett and GMEP team, 2014). This paper describes the key sets of raw data arising from the field survey element of GMEP, undertaken between 2013 and 2016.

\subsection{Introduction to the GMEP survey design}

While GMEP encompassed a range of different components, including modelling and socio-economic surveys, a field survey formed the largest element of the monitoring programme. The field survey was designed in such a way as to capture multiple measures and metrics and to integrate across these metrics. In order to do this, a full ecosystem-based approach was chosen such that data were captured across multiple scales, where possible during a single field visit. A 4year cycle rolling survey was adopted in order to maximise the number of sites visited at the national scale, while also monitoring year on year. This would allow for cost-effective detection of both spatial variation and temporal trends (Emmett and GMEP team, 2014). The first survey cycle dates from 2013 to 2016, with the potential for, and intention of, regular repeat surveys.

Across GMEP monitoring, integration of survey data was a priority; therefore, a common spatial unit of $1 \mathrm{~km}$ for the survey square was adopted. A total of three-hundred $1 \mathrm{~km}$ survey squares (Fig. 1) were sampled over the 4-year cycle. The $1 \mathrm{~km}$ dimension was a conveniently sized unit for landscape monitoring, which has been adopted by previous successful monitoring programmes. First tested for this type of monitoring in a small scale survey in Cumbria (1975) (Bunce and Smith, 1978) and Shetland (1974) (Wood and Bunce, 2016), the $1 \mathrm{~km}$ monitoring unit was later adopted for the Countryside Survey of Great Britain from 1978 (Bunce, 1979) to present day and is used by other current monitoring schemes, such as the Breeding Bird Survey (Harris et al., 2018) and the Wider Countryside Butterfly Survey (Brereton et al., 2011). The 300 GMEP field-survey squares were split evenly into two key components: the "Wider Wales Component", used for baseline estimation, national trends and national reporting of Glastir, and the "Targeted Component", which focussed on priority areas and aims of the Glastir scheme (Emmett and GMEP team, 2014).

The Wider Wales Component of GMEP comprised onehundred-and-fifty $1 \mathrm{~km}$ survey squares which were selected 


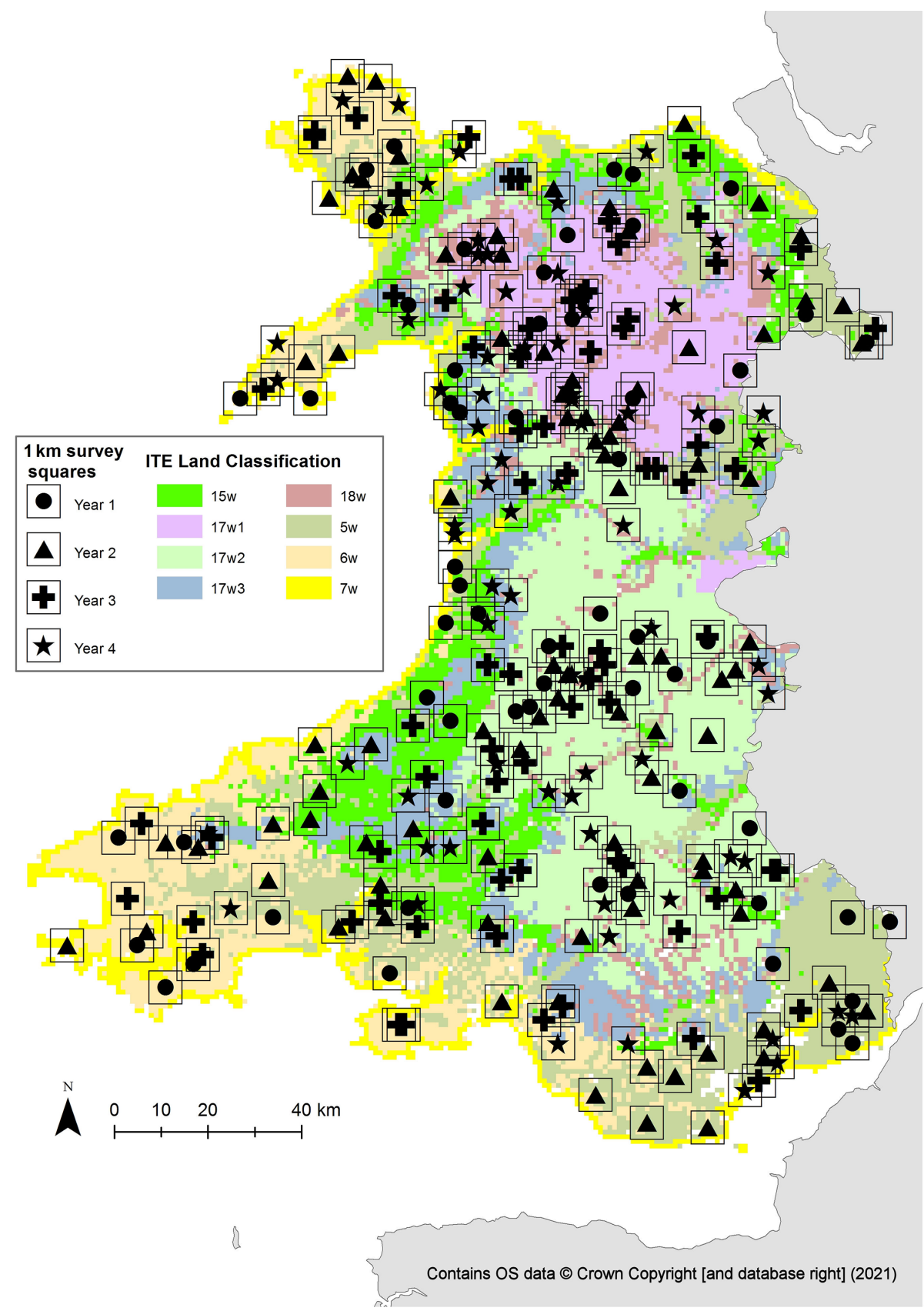

Figure 1. Map to show distribution of $1 \mathrm{~km}$ survey squares across different land classes in Wales (survey squares not shown to scale to preserve data confidentiality).

following the same procedure as used for the UK Centre for Ecology \& Hydrology (UKCEH) Countryside Survey of Great Britain (Carey et al., 2008; Norton et al., 2012), aiming to provide statistically robust estimates of indicators from 1978 to 2016 at national and sub-national levels. Thus, "Wider Wales" squares were a stratified-random sample of Wales, with proportional representation of strata defined according to the ITE Land Classification of Great Britain (henceforth "land classes") (Bunce et al., 2007; Em- mett and GMEP team, 2014). Land classes are derived from a statistical analysis of topographic, physiographic, geological and climatic attributes. Environmental heterogeneity is minimised within each land class and is maximised between land classes. The number of $1 \mathrm{~km}$ survey squares randomly sampled and sited from each land class was proportional to the area of that land class in Wales. This helped to optimise allocation of survey effort (Emmett et al., 2015). 


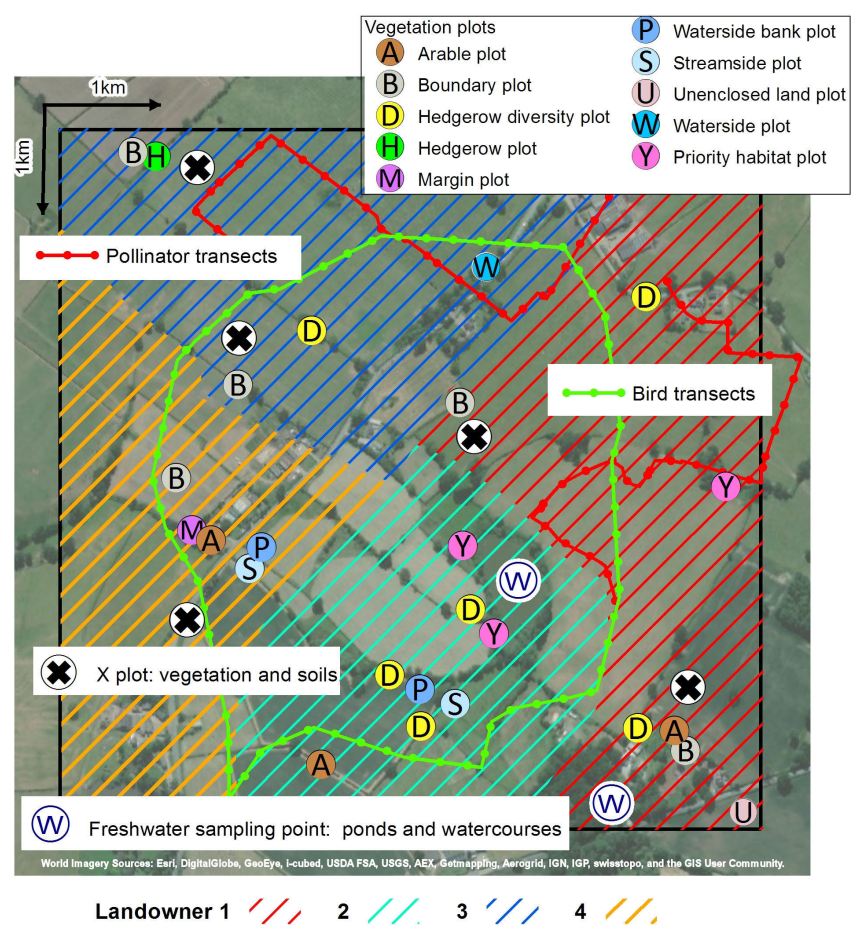

Figure 2. Type and distribution of published data collected in a typical $1 \mathrm{~km}$ survey square (excluding the land cover and land use mapping element; see Fig. 3) (Esri, 2021).

The other half of the sampled squares were targeted specifically at Glastir priority areas (Welsh Government, 2020). The squares were selected by calculating weights for each $1 \mathrm{~km}$ survey square across Wales that reflected the amount and diversity of Glastir uptake within the square (Emmett and GMEP team, 2014). Squares were then randomly selected with probability proportional to these assigned weights, such that a square with twice the weight as another was twice as likely to be selected. The weighting, and therefore selection of Targeted Component squares, was repeated each year as new information became available on Glastir uptake. Across both GMEP field-survey components, any square that contained more than $75 \%$ of urban land or that was more than $90 \%$ sea (defined by the UK Land Cover Map 2007, Morton et al., 2011, and mean high tide data, Ordnance Survey, 2020) was excluded and replaced according to the above procedures (Emmett and GMEP team, 2014).

\section{Data collected: field and laboratory collection methods}

A wide range of data were collected during the field survey, encompassing land use and cover, vegetation, soils, freshwaters, birds, and insect pollinators. Figure 2 illustrates the type and distribution of data collected in a typical $1 \mathrm{~km}$ survey square, and a short summary of each of the elements is provided in this section. In addition to these key, pub-

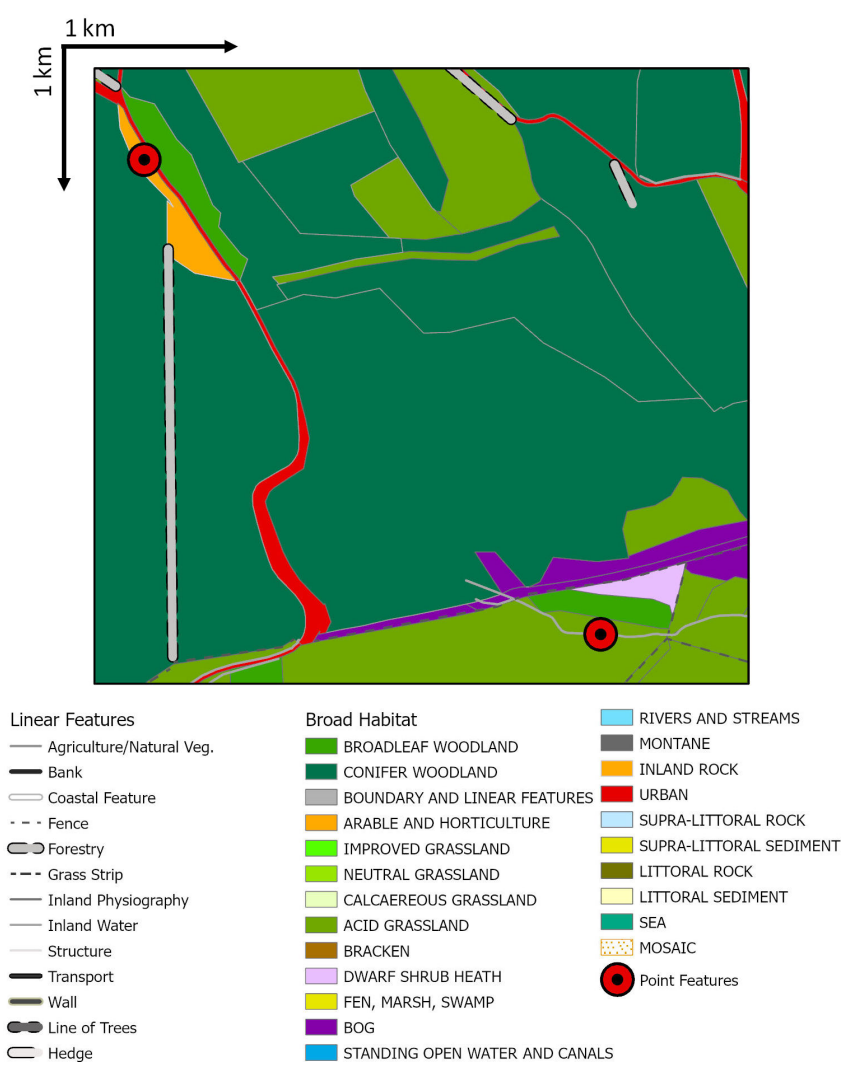

Figure 3. An example of a survey square, showing mapped point, line and area features (the key includes the full range of possible broad habitats and linear features, not all shown on the map).

lished datasets, ancillary information was collected at survey sites regarding landscapes (photographs), footpath and historic feature assessments.

\subsection{Land cover and land use}

The most geographically comprehensive element of the survey is the mapping of land cover and ecologically relevant landscape features (Fig. 3). The methods adopted were those of the UKCEH Countryside Survey, described in detail in Wood et al. (2018a). Across accessible areas of each $1 \mathrm{~km}$ survey square, areal, linear and point features were mapped digitally using Microsoft Windows 7-based electronic data capture equipment and electronic mapping software ("CS Surveyor") co-developed by the UK Centre for Ecology \& Hydrology and software company, Esri UK (Maskell et al., 2008). With the aid of base maps, each feature was assigned a range of pre-determined coded attributes (Maskell et al., 2008; Wood et al., 2018a). For area features, attributes for each mapped polygon included "biodiversity action plan" (BAP) broad/priority habitats (Jackson, 2000; Maddock, 2008), land use and land management (for example, crop, grazing animals, recreation, timber, burning), dominant vegetation species, and a variety of other descriptors ac- 
cording to the land use type (for example, road verge widths, tree diameter at breast height, woodland structure, woodland features and sward descriptions) (Wood et al., 2018b).

Linear features are landscape elements less than $5 \mathrm{~m}$ wide that form lines in the landscape (Wood et al., 2018b). Recording included the length and condition of a range of linear features predominantly, but not exclusively, describing boundaries. These include managed woody linear features (i.e. hedges), unmanaged woody linear features (i.e. lines of trees), walls, fences, streams and a range of other linear features. Recorded linear features have a minimum length of $20 \mathrm{~m}$ and may include gaps of up to $20 \mathrm{~m}$ (a rule agreed with hedgerow experts when compiling methods for UKCEH Countryside Survey, Maskell, 2008). All linear features were recorded unless they form part of a curtilage or they are within the woodland canopy. Woody linear features, including hedges, remnant hedges and lines of trees were classified using a key (Maskell et al., 2016a), following consultation with the Hedgerow Steering Group of the UK BAP (Wood et al., 2018b).

Point features are individual landscape elements that occupy an area of less than $20 \mathrm{~m} \times 20 \mathrm{~m}$. Point features may be trees or groups of trees, ponds and other freshwater features, physiographic features such as cliffs, buildings and other structures with various use codes (for example, "residential" or "agricultural") (Wood et al., 2018b). For the detailed methodology, see the GMEP field mapping handbooks (Maskell et al., 2016a, b). Quality assurance was achieved by ensuring surveyors were trained appropriately before each field season, visits to surveyors in the field by supervisors and the repeat survey of a number of squares to identify any issues arising.

\subsection{Vegetation plots}

The vegetation element of the field survey involved recording plant species presence and cover in different sizes and types of vegetation plot (Table 1), comprising different numbers of "nests" (i.e. subsections of the plot). The design of the plots originated in the UKCEH Countryside Survey, and the history and logic behind their positioning is described fully in Wood et al. (2017). A comprehensive description of these plots may be found in the field survey handbook (Smart et al., 2016) with a summary presented in Table 1. In each vegetation plot, a complete list of all vascular plants and a selected range of readily identifiable bryophytes and macro-lichens was made, with the exception of "D" (Diversity) plots, in which only woody species in hedgerows were recorded (Wood et al., 2017). Cover estimates were made to the nearest $5 \%$ for all species reaching at least an estimated 5\% cover. Presence was recorded if cover was less than $5 \%$. Canopy cover of overhanging trees and shrubs was also noted, alongside general information about the plot. To ensure quality, the field training courses held before the surveys covered identification of difficult species, regular visits were made to survey teams by managers, and difficult specimens could be collected and sent to experts for identification (Wood et al., 2017). A number of plots were repeated by quality assessors to ensure consistency of quality within the survey (Wood et al., 2017).

\subsection{Soils}

Within each of the three-hundred $1 \mathrm{~km}$ sample squares, the key soil measurements described below were taken from a set of three volumetric topsoil samples $(0-15 \mathrm{~cm})$ sampled from each of five pre-determined randomly dispersed locations, using standard-sized plastic tubes and a metal coring implement. The sampling locations were coincident with the five large ("random"/“main"/"X") vegetation plots (Table 1). Sampling started on the southern corner of the inner $2 \times 2 \mathrm{~m}$ nest of the $\mathrm{X}$ plot in 2013 and then proceeded west, north and east in the consecutive years. Soil samples included one sample analysed for physico-chemical soil metrics, taken using a black plastic core $(15 \mathrm{~cm}$ long $\times 5 \mathrm{~cm}$ diameter); a spare white core $(15 \mathrm{~cm}$ long $\times 5 \mathrm{~cm}$ diameter); and a sample for soil fauna (2013 and 2014), taken using a shorter core ( $8 \mathrm{~cm}$ long). In 2013 and 2014, five bulked 0$15 \mathrm{~cm}$ gouge auger samples for DNA metabarcoding were also taken and were frozen upon receipt at the laboratory until analysis. The methods for this area of work is outlined in George et al. (2019a). After collection, the soil cores were refrigerated and stored until posted, usually within $2 \mathrm{~d}$, to laboratories at the UK Centre for Ecology \& Hydrology in Bangor and Lancaster for analysis and/or archive storage in air-dried or frozen form.

\subsubsection{Physico-chemical properties}

The sample taken for analysing physico-chemical properties included measurements of the following properties: loss on ignition (LOI) and derived carbon concentration, total soil organic carbon (SOC) and nitrogen, total soil phosphorous, Olsen phosphorous, soil $\mathrm{pH}$ (in deionised water and calcium chloride), soil solution electrical conductivity, soil bulk density of fine earth, fine earth volumetric water content (where sampled), soil water repellency, and water drop penetration time. The methods for these are summarised in Table 2.

\subsubsection{Soil meso-fauna}

Soil meso-fauna were extracted using the standard Tullgren funnel method (Southwood, 1994), as used in the UKCEH Countryside Survey (Emmett et al., 2008). Following the extraction procedure, the samples were sorted, identified and enumerated according to broad groups (as shown in Table 3) by trained staff and students (Emmett et al., 2008). These enumerated broad groups were entered into data template spreadsheets and, once complete, sent to UKCEH Bangor for integration into the database. 
Table 1. Plot types included in GMEP (Smart et al., 2016).

\begin{tabular}{|c|c|c|c|c|c|}
\hline Code & Name & Where & Size & $\begin{array}{l}\text { No. per } 1 \mathrm{~km} \\
\text { survey square }\end{array}$ & $\begin{array}{l}\text { Additional information } \\
\text { (sampling followed standard } \\
\text { protocols established by the } \\
\text { UKCEH Countryside Survey } \\
\text { https://countrysidesurvey.org.uk/, } \\
\text { last access: } 13 \text { August 2021, unless } \\
\text { stated below) }\end{array}$ \\
\hline$X$ & $\begin{array}{l}\text { Random/main/ } \\
\text { X plot }\end{array}$ & $\begin{array}{l}\text { Dispersed random points (not on linear } \\
\text { features). }\end{array}$ & $\begin{array}{l}4 \mathrm{~m}^{2} \\
\text { or } 200 \mathrm{~m}^{2}\end{array}$ & Up to 5 & $\begin{array}{l}\text { In years 2013-2014, all X plots } \\
\text { were } 200 \mathrm{~m}^{2} \text {. In 2015-2016, due to } \\
\text { resource limitations, plots were re- } \\
\text { duced to } 4 \mathrm{~m}^{2} \text { (with the exception } \\
\text { of woodland habitats and a small } \\
\text { subset of squares). }\end{array}$ \\
\hline Y & $\begin{array}{l}\text { Small: targeted } \\
\text { and } \\
\text { enclosed/habitat }\end{array}$ & $\begin{array}{l}\text { Primarily allocated to "enclosed habi- } \\
\text { tats" in or out of Glastir option and } \\
\text { then additionally placed to record prior- } \\
\text { ity habitats (PH) not sampled by other } \\
\text { plots. }\end{array}$ & $4 \mathrm{~m}^{2}$ & $\begin{array}{l}\text { Up to } 5 \text { but } \\
\text { more if }>5 \mathrm{PH}\end{array}$ & $*$ \\
\hline $\mathrm{U}$ & Unenclosed & $\begin{array}{l}\text { Unenclosed broad habitats in or out of } \\
\text { Glastir options. }\end{array}$ & $4 \mathrm{~m}^{2}$ & Up to 10 & $*$ \\
\hline B & Boundary & $\begin{array}{l}\text { Adjacent to field boundaries in or out } \\
\text { of Glastir option; randomly located in } \\
\text { relation to the X plot. }\end{array}$ & $10 \times 1 \mathrm{~m}$ & 5 & $*$ \\
\hline A & Arable & $\begin{array}{l}\text { Arable field edges centred on each B } \\
\text { plot; in or out of Glastir option but only } \\
\text { one per arable field; paired with X plots } \\
\text { if out of option. }\end{array}$ & $100 \times 1 \mathrm{~m}$ & Up to 5 & $*$ \\
\hline M & Margin & $\begin{array}{l}\text { Field margins in or out of Glastir op- } \\
\text { tion. }\end{array}$ & $2 \times 2 \mathrm{~m}$ & Up to 15 & $*$ \\
\hline $\mathrm{H}$ & Hedgerow & $\begin{array}{l}\text { Alongside hedgerows (i.e. woody linear } \\
\text { feature (WLF) with unnatural shape) } \\
\text { and usually coincident with two of the } \\
\text { D plots; randomly located in relation to } \\
\text { the X plots. }\end{array}$ & $10 \times 1 \mathrm{~m}$ & 2 & \\
\hline D & $\begin{array}{l}\text { Hedgerow } \\
\text { diversity }\end{array}$ & $\begin{array}{l}\text { WLF with natural or unnatural shape; } \\
\text { allocated proportionally to WLF in Gla- } \\
\text { stir option; randomly located in relation } \\
\text { to the X plots. }\end{array}$ & $30 \times 1 \mathrm{~m}$ & Up to 10 & $*$ \\
\hline $\mathrm{S} / \mathrm{W}$ & Streamside & $\begin{array}{l}\text { Four placed alongside watercourses and } \\
\text { allocated in proportion to Glastir option } \\
\text { uptake; one W plot centred on the river } \\
\text { habitat survey (RHS) stretch. }\end{array}$ & $10 \times 1 \mathrm{~m}$ & Up to 5 & $*$ \\
\hline $\mathrm{P}$ & $\begin{array}{l}\text { Perpendicular } \\
\text { streamside }\end{array}$ & $\begin{array}{l}\text { Sampling the upslope habitats adjacent } \\
\text { to and centred on the S/W plots. }\end{array}$ & $10 \times 1 \mathrm{~m}$ & Up to 5 & $\begin{array}{l}\text { A new type of plot for the GMEP } \\
\text { survey; nests within these plots are } \\
\text { of variable length, summing to } 10 \mathrm{~m} \\
\text { (Emmett et al., 2015). }\end{array}$ \\
\hline $\mathrm{R} / \mathrm{V}$ & $\begin{array}{l}\text { Roadside verge } \\
\text { plots }\end{array}$ & $\begin{array}{l}\text { Sampling the } 1 \mathrm{~m} \text { strip adjacent to roads } \\
\text { and tracks. }\end{array}$ & $10 \times 1 \mathrm{~m}$ & Up to 5 & $\begin{array}{l}\text { Only recorded in 2016, in a subset } \\
\text { of squares. }\end{array}$ \\
\hline
\end{tabular}

\footnotetext{
* Location of these plots incorporated additional targeting to take into account the proportional amount of Glastir options in a $1 \mathrm{~km}$ survey square.
} 
Table 2. Summary of soil physico-chemical properties and measurement methods.

\begin{abstract}
i. Loss on ignition
Loss on ignition (LOI) is a simple and inexpensive method for determining soil organic matter and estimating soil organic carbon concentration. The method was the same standard method as that used in the UKCEH Countryside Survey (Emmett et al., 2010). LOI was measured on a $10 \mathrm{~g}$ air-dried sub-sample taken after sieving to $2 \mathrm{~mm}$, then dried at $105^{\circ} \mathrm{C}$ for $16 \mathrm{~h}$ to remove moisture, weighed, and then combusted at $375^{\circ} \mathrm{C}$ for $16 \mathrm{~h}$. The cooled sample was then weighed and the LOI (\%) calculated (Emmett et al., 2010). In order to have data that were compatible with legacy data from other surveys, like UKCEH Countryside Survey, carbon (C) concentration was derived from the LOI measurement. Resulting $\mathrm{C}$ concentration measures, unlike those from some other methods, were thus unaffected by soil inorganic carbon. The formula for deriving $\mathrm{C}$ concentration is

$\mathrm{C}$ concentration $\left(\mathrm{g} \mathrm{Ckg}^{-1}\right)=\mathrm{LOI}(\%) \cdot 0.55 \cdot 10$.

LOI quality control checks were carried out using internal soil standards prepared in an identical manner to the sampled soils. Two different internal standards were included in each sample batch. Those internal standards were compared with a historically generated mean value for internal standards. If the measured LOI for the two internal standards in a batch varied by more than 2 standard deviations, in either direction, from the historic mean value, then the batch was repeated.
\end{abstract}

ii. Total soil organic carbon (SOC) and nitrogen

This analysis was carried out using the United Kingdom Accreditation Service (UKAS) accredited method SOP3102, at UKCEH Lancaster. Soil samples were air-dried (at $\left.40^{\circ} \mathrm{C}\right)$, ball milled and oven-dried at $105^{\circ} \mathrm{C}\left( \pm 5^{\circ} \mathrm{C}\right)$ for a minimum of $3 \mathrm{~h}$. Samples were then analysed using an Elementar Vario EL elemental analyser (Elementar Analysensysteme GmbH, Hanau, Germany), which is a fully automated analytical instrument working on the principle of oxidative combustion followed by thermal conductivity detection. Following combustion in the presence of excess oxygen, the oxides of nitrogen $(\mathrm{N})$ and carbon $(\mathrm{C})$ flow through a reduction column which removes excess oxygen. $\mathrm{C}$ is trapped on a column whilst $\mathrm{N}$ is carried to a detector. $\mathrm{C}$ is then released from the trap and detected separately. Sample weights are usually $15 \mathrm{mg}$ for peat and $15-60 \mathrm{mg}$ for mineral soil samples (Emmett et al., 2010). Quality control was achieved by use of two in-house reference materials analysed with each batch of samples.

iii. Total soil phosphorous $(\mathrm{P})$

Air-dried and ground (to $2 \mathrm{~mm}$ ) soils were digested with hydrogen peroxide (100 volumes) and sulfuric acid in a $5: 6$ ratio. Selenium powder and lithium sulfate were added to raise the boiling point of the acid.

Samples were then heated at $250^{\circ} \mathrm{C}$ for $15 \mathrm{~min}$ and then to $400^{\circ} \mathrm{C}$ where the temperature was maintained for $2 \mathrm{~h}$ to complete the digestion. After digestion, the samples were diluted with ultrapure water and allowed to settle overnight. The supernatant was then further diluted and P was measured colourimetrically using a SEAL AQ2 discrete analyser. Phosphorus was determined using ammonium molybdenum blue chemistry with the addition of ascorbic acid to control the colour production. Two quality controlled reference samples, a duplicate sample and two matrix matched blanks were run every 25 samples to ensure data quality. The final concentration $\left(\mathrm{mg} \mathrm{kg}^{-1}\right)$ was determined using a calibration curve of the standard and took into account the blank concentration.

iv. Olsen phosphorous

Olsen phosphorous was measured in samples from arable and improved grassland habitats only, where the measurement is most reliable (Emmett et al., 2010). Two grams of air-dried soil samples were extracted in $40 \mathrm{~mL}$ Olsen's reagent $\left(0.5 \mathrm{M} \mathrm{NaHCO}_{3}\right.$ at $\left.\mathrm{pH} 8.5\right)$ for $30 \mathrm{~min}$ in a mechanical end-over-end shaker. The sample was then filtered through a Whatman 44 filter paper to separate the soil and the filtrate; the filtrate is kept for analysis. The analysis was performed on a Seal Analytical AA3 segmented flow. The samples were mixed in the flow channel with an acidic ammonium molybdate and potassium antimony tartrate to form a complex with phosphate. This complex was reduced with ascorbic acid to develop a molybdenum blue colour. The reaction was temperature controlled to $40{ }^{\circ} \mathrm{C}$ using a water bath to ensure uniform colour development. The developed colour was measured at $880 \mathrm{~nm}$.

Two quality controlled reference samples, a duplicate sample and two blanks were run every 25 samples to ensure data quality. The final concentration is expressed in milligrams per kilogram $\left(\mathrm{mg} \mathrm{kg}^{-1}\right)$ and is for moisture content, the concentration of the blank and using a calibration curve of the standard.

v. Soil $\mathrm{pH}$ measurements in deionised water and calcium chloride $\left(\mathrm{CaCl}_{2}\right)$

Soil $\mathrm{pH}$ was carried out on a suspension of fresh field-moist soil in deionised water and $0.01 \mathrm{M} \mathrm{CaCl}_{2}$. The ratio of soil to water or $\mathrm{CaCl}_{2}$ was $1: 2.5$ by weight. The method used was based upon that employed by the Soil Survey of England and Wales (Avery and Bascomb, 1974). Two different internal standards were included in each sample batch for quality control. Batches in which the measured $\mathrm{pH}$ for the internal standards varied by more than 2 standard deviations in either direction from the mean value generated historically for the internal standards were repeated. 
Table 2. Continued.

vi. Soil solution electrical conductivity

Ten grams of field-moist soil was weighed into a beaker with $25 \mathrm{~mL}$ of deionised water added and then stirred with a rod to produce a homogeneous suspension. After half an hour, the contents of the beaker were stirred again with the rod, and the electrical conductivity (EC) was measured using an electrode and a conductivity meter (Jenway 4510). For quality control, two different internal standards were included in each sample batch. Those internal standards were compared with a historically generated mean value for internal standards. If the measured EC for the two internal standards in a batch varied by more than 2 standard deviations, in either direction, from the historic mean value, then the batch was repeated.

vii. Soil bulk density of fine earth and volumetric water content of fine earth

The bulk density (BD) of soil depends greatly on the mineral make up of soil, soil organic matter and the degree of compaction. It is a measure of the amount of soil per unit volume and is therefore an excellent measure of available pore space in a soil, and gives information on the physical status of the soil. BD values are also essential when estimating soil $\mathrm{C}$ stocks, as they allow for a conversion from $\% \mathrm{C}$ to $\mathrm{C}$ per unit volume. Bulk density was determined from a core which is $15 \mathrm{~cm}$ long with a diameter of $5 \mathrm{~cm}$. Dry bulk density is calculated using the following equation:

Dry bulk density $\left(\mathrm{g} \mathrm{cm}^{-3}\right)=\frac{\left(\text { Dry weight core }\left(105^{\circ} \mathrm{C}\right)(\mathrm{g})-\text { stone weight }(\mathrm{g})\right)}{\left(\text { Core volume }\left(\mathrm{cm}^{-3}\right)-\text { stone volume }\left(\mathrm{cm}^{-3}\right)\right)}$.

viii. Fine earth volumetric water content when sampled

Once the bulk density was calculated, the volumetric water content of the fine earth fraction could be determined by multiplying the bulk density and the gravimetric water content of the fine earth. Quality control was achieved by using fixed volume pre-cut sleeves for soil sampling and extensive training for soil surveyors.

ix. Soil water repellency and water drop penetration time

Soil water repellency (surface) measurement was carried out by measuring the time for a fixed volume droplet of deionised water $(100 \mu \mathrm{L})$ to be fully absorbed into the soil surface (water drop penetration time, WDPT). Six drops of water were applied to an air-dried undisturbed soil surface. The entire process was filmed using a digital video camera so that the timing could be determined accurately. The samples were maintained in a laboratory at a relatively constant temperature $\sim 20^{\circ} \mathrm{C}$. Some soils, especially arable, were not consolidated so measurements were taken on surface unconsolidated soil or aggregates using $20 \mathrm{~g}$ soil added to a tin lid and procedure followed as described above. For quality control, a micropipette was used to deliver the drops, six drops were used, and then the median value was obtained. All drop penetration measurements were captured using video, so times of penetration can be reviewed if required.

Table 3. Soil meso-fauna.

\begin{tabular}{|c|c|c|c|}
\hline \multicolumn{3}{|c|}{ Enumerated broad groups } & \multirow{2}{*}{$\begin{array}{l}\text { Details } \\
\text { Commonly known as "box" mites; these decomposers tend to be abundant in } \\
\text { woodlands. }\end{array}$} \\
\hline 1 & Acari & Oribatid - Phthiracaridae & \\
\hline 2 & & Oribatid - others & Other oribatid mites, mostly decomposers or microbial feeders. \\
\hline 3 & & Mesostigmatid & Predatory mites which feed on other soil meso-fauna. \\
\hline 4 & & Other & $\begin{array}{l}\text { Typically small mites; largely containing prostigmatids and juvenile mesostig- } \\
\text { matids. }\end{array}$ \\
\hline 5 & Collembola & Poduromorpha & Podurid Collembolans; short legs and plump body shape. \\
\hline 6 & & Entomobryomorpha & Entomobryid Collembolans; generally with long, slender body. \\
\hline 7 & & Symphypleona/Neelipleona & Symphypleonid Collembolans; small, round, globular body shape. \\
\hline 8 & & Total oribatids & $1+2$ \\
\hline 9 & & Total mites & $1+2+3+4$ \\
\hline 10 & & Total Collembolans & $5+6+7$ \\
\hline 11 & & Total meso-fauna & $1+2+3+4+5+6+7$ \\
\hline
\end{tabular}


For the purpose of quality control, another member of staff checked 1 in 20 samples for the first 200 samples. Fauna were then identified and enumerated by both members of staff to ensure that the identification and counting procedures employed by both individuals produced comparable results. This process was repeated at a reduced rate as the identifications proceeded (Emmett et al., 2008).

\subsubsection{Particle size distribution (PSD)}

The particle size distribution (PSD) of a soil, typically presented as the proportions of clay $(<2 \mu \mathrm{m})$, silt $(2-63 \mu \mathrm{m})$ and sand $(63-2000 \mu \mathrm{m})$, is a fundamental property of the soil. It controls nearly all edaphic processes and exerts strong control on hydrology, transport of pollutants, availability of nutrients, stabilisation of soil organic matter, mechanisms of erosion, gas exchange, soil biota and aboveground productivity. The method of laser diffraction (LD) emerged in the 1980s as a potentially powerful tool for analysing granular materials, and in the 1990s the soil science community began to apply LD to soils (e.g. Lebron et al., 1993). The method has the advantage of being quick (about 5 min per sample), requires small amounts of soil $(<2.0 \mathrm{~g})$, is reproducible and provides a wide range of size classes (rather than the conventional 3 to 9 ).

For GMEP, particle size distribution was analysed in samples with a loss on ignition lower than $50 \%$ using a Beckman Coulter LS13 320 laser diffraction particle size analyser (Beckman Coulter Inc.) and the hydrometer method (Gee and Or, 2002) (Emmett et al., 2015). Standard soil samples were included with each batch of samples, and duplicated samples were included ( 1 in 10 ) to check for reproducibility. To evaluate the accuracy of the instrument, different-sized standards were used: nominal $500 \mu \mathrm{m}$ glass beads (Beckman Coulter Inc.) and nominal $15 \mu \mathrm{m}$ garnet (Beckman Coulter Inc.). Sandy soil from Gleadthorpe (Cuckney, UK), clay soil from Brimstone (Denchworth, UK) and a silty soil from Rosemaud (Bromyard, UK) were also used. All three soils are well-characterised farm soils from ADAS Ltd. In addition, two well-characterised internal soil standards from the UKCEH laboratory were used (loam and silty clay loam).

The sand fraction was collected with a $63 \mu \mathrm{m}$ sieve at the end of the drainage outlet. As a way to corroborate the laser measurements, the weight of the sand collected in the sieve at the end of the measurement was compared with the data provided by the instrument. In general, there was a good agreement for both values for the sand fraction. However, high content of organic matter interference with the laser measurements was observed. After removal of organic matter, when the soil is very organic (loss on ignition (LOI) values of $40 \%-50 \%$ ), there are still some recalcitrant organic materials that persist in the soil and produce overestimation of the sand fraction measure with LD.

\subsection{Freshwaters}

A range of different types of data were collected from the freshwater habitats of headwater streams and ponds. Data were collected across the three-hundred $1 \mathrm{~km}$ survey sites, where the features occurred.

\subsubsection{Headwater streams}

Data were collected from selected sections of headwater streams, where present, in up to three-hundred $1 \mathrm{~km}$ squares according to standardised field methods (Kelly et al., 1998; Murray-Bligh, 1999; O'Hare et al., 2013). Sampling points were generally chosen to enable a full River Habitat Survey (River Habitat Survey, 2021) to be taken in the square, while also being as close as possible to an access point into the square. Data relating to this freshwater element of the survey are summarised in Table 4.

\subsubsection{Ponds}

A bottled water sample was taken from a pond selected at random from each $1 \mathrm{~km}$ survey site where present (a size constraint was used with a pond defined as "a body of standing water $25 \mathrm{~m}^{2}$ to 2 ha in area which usually holds water for at least 4 months of the year"). The sample was sent to the laboratories at the UK Centre for Ecology \& Hydrology, Lancaster. The samples were analysed according to accredited methods as described for headwater streams in Table 4.

To calculate pond biological quality, the method of the Freshwater Habitats Trust (Predictive SYstem for Multimetrics - PSYM) was used. This is a standardised method (Howard, 2002) and is summarised as follows.

PSYM was developed to provide a method for assessing the biological quality of still waters in England and Wales. The method uses a number of aquatic plant and invertebrate measures (known as metrics), which are combined together to give a single value which represents the waterbody's overall quality status (Williams et al., 1996). Using the method involves the following steps:

1. Simple environmental data are gathered for each waterbody from map or field evidence (area, grid reference, geology, etc.).

2. Biological surveys of the plant and animal communities are undertaken and net samples are processed.

3. The biological and environmental data are entered into the PSYM computer programme, which

i. uses the environmental data to predict which plants and animals should be present in the waterbody if it is un-degraded and

ii. takes the real plant and animal lists and calculates a number of metrics. 
Table 4. Summary of freshwater properties and measurement methods.

i. Diatoms

Samples were digested using hydrogen peroxide to remove organic matter and mounted on slides using the mountant Naphrax. At least 300 valves on each slide were identified to the highest resolution possible using a Nikon BX40 microscope with $100 \times$ oil immersion objective with phase contrast. The primary floras and identification guides used were Krammer and Lange-Bertalot (1986, 2000, 1997, 2004), Hartley (1996) and Hofmann et al. (2011). All nomenclature was adjusted to that used by Whitton et al. (1998), which follows conventions in Round et al. (2007) and Fourtanier and Kociolek (1999). Members of the Achnanthidium minutissimum complex showed considerable morphological variability and were classified using the conventions in Potapova and Hamilton (2007).

ii. Invertebrates

Initially, samples were prepared by washing and sieving. Small portions of the samples were placed into a water filled sorting tray, marked with a grid to act as an aid, and systematically scanned for invertebrates. Examples of all taxa were placed into vials for quality assurance. After the first sort, the sample was then disturbed and/or rotated to expose previously hidden taxa. The process was repeated until all necessary taxa had been removed from the sample.

Macroinvertebrates removed from the sample were identified to species level where possible, including Caddis and Diptera pupae but with the exception of Oligochaeta, Chironomidae, Simuliidae and Hydracarina. The majority of identification work was conducted using dissection microscopes with high-power microscopes used for examination of small specimens or specific parts of specimens. Terrestrial and aerial stages of aquatic species, terrestrial species and specimens which were dead when collected were not counted. Invertebrates which had become fragmented were only counted as a record if the thorax and abdomen were present. If only the posterior, abdomen or head was present, the species was not recorded.

Though the abundances of taxa were not necessary for the Biological Monitoring Working Party (BMWP) water quality scoring system, they were recorded for use in other indices and environmental diagnostics. Only free-living individuals were counted. Colonies were counted as one individual. Very abundant taxa were recorded by distributing the sample evenly, counting the specimens in a portion of the tray using the grid lines and calculating the total by proportions. Quality control was carried out by the reanalysis of 1 randomly selected sample in every 20 by a different analyst.

iii. Water chemistry

Bottled water samples were sent to the laboratories at the UK Centre for Ecology \& Hydrology, Lancaster, and were analysed according to accredited methods as described below:

Phosphate $\left(\mathrm{PO}_{4}-\mathrm{P}\right)$.

$\mathrm{PO}_{4}-\mathrm{P}$ concentrations were measured colourimetrically using a Seal Analytical AQ2 discrete analyser. $\mathrm{PO}_{4}-\mathrm{P}$ was determined by reaction with acidic molybdate in the presence of antimony to form an antimony-phosphomolybdate complex. Ascorbic acid reduced this to the intensely blue phosphomolybdenum complex, measured spectrophotometrically at $880 \mathrm{~nm}$. Calibration was produced by automatic dilution of a single stock solution of $0.2 \mathrm{mg} \mathrm{L}^{-1} \mathrm{PO}_{4}-\mathrm{P}$; concentrations were obtained using the calibration curve within the range $0-0.2 \mathrm{mg} \mathrm{L}^{-1}$. Control standards of $0.1 \mathrm{mg} \mathrm{L}^{-1} \mathrm{PO}_{4}-\mathrm{P}$ were analysed every 10 samples.

Total dissolved nitrogen (TDN).

A Skalar Formacs CA16 analyser with an attached ND25 filter was used to measure total dissolved nitrogen in water samples. TDN was measured by combustion at $900^{\circ} \mathrm{C}$ with a cobalt chromium catalyst which converts all nitrogen to nitric oxide. The nitric oxide was measured by a chemiluminescent reaction with ozone. The calibration range of the instrument was $0-4 \mathrm{mg} \mathrm{L}^{-1}$ for nitrogen. Samples with values over this range were diluted to within the range using $18.2 \mathrm{M} \Omega$ carbon-free water.

Alkalinity.

Alkalinity was determined using a standard operating procedure for alkalinity in waters. Alkalinity was determined using the Mettler Toledo DL53 titrator, which performs analyses automatically using predefined methods. A complete titration method comprised sample dilution, dispensing of acid, stirring and waiting times, the actual titration, the calculation of results, and a report.

Reagents and material used include standard buffer solutions from Fisher Scientific of $\mathrm{pH} 4$ and $\mathrm{pH}$ 7, electrode filling solution made with potassium chloride solution (4 M) saturated with silver chloride from Fisher Scientific, 1.0 M hydrochloric acid, $0.02 \mathrm{M}$ hydrochloric acid, $1000 \mathrm{mg} \mathrm{L}^{-1}$ stock solution as calcium carbonate, $20 \mathrm{mg} \mathrm{L}^{-1}$ quality controlled standard as calcium carbonate, and deionised water. Alkalinity (usually) reflects the activity of calcium carbonate, so results were reported as milligrams per litre of calcium carbonate $\left(\mathrm{mgL}^{-1} \mathrm{CaCO}_{3}\right)$. 
Finally the programme compares the predicted plant and animal metrics with the real survey metrics to see how similar they are (i.e. how near the waterbody currently is to its ideal/un-degraded state). The metric scores are then combined to provide a single value which summarises the overall ecological quality of the waterbody. Where appropriate, individual metric scores can also be examined to help diagnose the causes of any observed degradation (e.g. eutrophication, metal contamination) (Williams et al., 1996).

\subsection{Birds}

Bird surveys were coordinated by the British Trust for Ornithology (BTO). The survey protocol (Siriwardena and Taylor, 2014) was designed to provide a robust estimate of the total numbers of breeding pairs of birds of each species found in each $1 \mathrm{~km}$ survey square and thus of change over time in future surveys, as well as information on the habitat patches in which individuals were recorded. Thus, the results provide information on local abundance and the selection of habitat types, such as areas under Glastir habitat management (Emmett and GMEP team, 2014). The protocol operates at the same spatial scale as the national BTO/JNCC/RSPB Breeding Bird Survey (BBS) (Harris et al., 2019) but involves more intensive fieldwork, so it provides more accurate measures of local abundance and is more appropriate for surveying smaller samples of squares each year (60-90 vs. thousands), with lower rates of repetition (Emmett and GMEP team, 2014). Measurement of habitat selection at the patch level also represents a finer scale of inference than is available from the BBS, which aggregates birds and habitats at the scale of the $200 \mathrm{~m}$ transect section. The field methods used thus incorporated elements of the BTO's previous national bird monitoring scheme, the Common Birds Census (O’Connor, 1990).

The surveys consisted of four (reduced to three from 2015-2016 onwards) visits to each square by trained, professional BTO surveyors (Siriwardena et al., 2020). Surveys were equally spaced through mid-March to mid-July. On each visit, the surveyor walked a route that passed within $50 \mathrm{~m}$ of all parts of the survey square to which access had been secured, beginning at around 06:00 (all times in this paper are given in local time) and taking up to $5 \mathrm{~h}$. Surveys were not conducted in conditions known to affect the detection of birds, i.e. strong winds and more than light rain. The survey route was started in different places on each visit so that all areas were visited at least once before 08:00. All birds seen or heard were recorded on high-resolution field maps using standard BTO activity codes. Recording and standardising route coverage (where surveyors actually walked) was important both between visits and to ensure comparable repeat coverage when squares are revisited (Siriwardena et al., 2020). The method is a distillation of the approach used for the BTO's Common Birds Census between 1962 and 2000 (O’Connor, 1990).

\subsection{Pollinators}

Each of the three-hundred $1 \mathrm{~km}$ survey squares was visited twice (once each in July and August) in 1 year between 2013 and 2016. Butterfly Conservation (BC) subcontracted nine experienced ecologists to survey $1 \mathrm{~km}$ survey squares across six regions of Wales (Emmett and GMEP team, 2014). A further region was covered by a BC employee. Pollinator surveys focused on three main pollinator groups: butterflies (Lepidoptera: Rhopalocera), bees (Hymenoptera: Apoidea) and hoverflies (Diptera: Syrphidae). Butterflies were recorded to species level, whilst bees and hoverflies were recorded as groups based on broad differences in morphological features associated with ecological differences. Note that training was critical for identification of these groups, particularly hoverflies. In addition, the abundance of common flowering plant groups (identified at the time of survey) was recorded using the DAFOR-X scale (D (dominant): $>30 \%, \mathrm{~A}$ (abundant): $11 \%-30 \%, \mathrm{~F}$ (frequent): $6 \%-10 \%, \mathrm{O}$ (occasional): $2 \%-5 \%, \mathrm{R}$ (rare): $0 \%-$ $1 \%, \mathrm{X}$, not seen on route) (Emmett and GMEP team, 2014).

Survey visits were split into two independent parts: (1) a standardised $2 \mathrm{~km}$ transect route through each $1 \mathrm{~km}$ survey square, established following the Wider Countryside Butterfly Survey (WCBS) method (Brereton et al., 2011; UKBMS, 2020), which uses Pollard walks (Pollard, 1977), as used in the UK Butterfly Monitoring Scheme (Brereton et al., 2019), and (2) a timed search in a $150 \mathrm{~m}^{2}$ flower-rich area within the square.

The transect route was split into two approximately parallel $1 \mathrm{~km}$ routes separated by at least $500 \mathrm{~m}$, and where possible at least $250 \mathrm{~m}$ in from the edge of the square. These routes were subdivided into ten $200 \mathrm{~m}$ sections. Flexibility in the route was allowed based on the presence of barriers such as roads and railways, urban areas, and refused access permission. In each section the number of each butterfly species and bee and hoverfly group within a $5 \mathrm{~m}^{2}$ recording box were recorded while walking the transect route at a steady pace. The DAFOR-X abundance of key flowering plant groups (selected on the basis of being known to be important plant groups for pollinating insects) was also recorded within the $5 \mathrm{~m}^{2}$ recording box. At the end of the transect walk, the weather conditions were recorded: temperature $\left({ }^{\circ} \mathrm{C}\right)$, sunshine $(\%)$ and wind speed (Beaufort scale) (Emmett and GMEP team, 2014).

For the timed searches, surveyors identified a $150 \mathrm{~m}^{2}$ flower-rich area within the $1 \mathrm{~km}$ survey square. In this area numbers of butterfly species and bee and hoverfly groups (the same groups as for the transect recording) seen within a 20 min period were counted. Surveyors also recorded which flowering plant group, if any, these pollinators were visiting.

Surveys were only conducted between 10:00 and 16:00 or between 09:30 and 16:30 if $>75 \%$ of the survey area was un-shaded and weather conditions were suitable for insect activity. The criteria for suitable weather were temperature 
between 11 and $17^{\circ} \mathrm{C}$ with at least $60 \%$ sunshine or above $17^{\circ} \mathrm{C}$, regardless of sunshine, and with a wind speed below 5 on the Beaufort scale ("small trees in leaf sway") (Emmett and GMEP team, 2014).

\subsection{Quality assurance}

In addition to specific measures already described for each element, Department for Environment Food and Rural Affairs (DEFRA) Joint Codes of Practice (JCoPR) were followed throughout (DEFRA, 2015). The JCoPR sets out standards for the quality of science and the quality of research processes. This helps ensure the aims and approaches of research are robust. It also gives confidence that processes and procedures used to gather and interpret the results of research are appropriate, rigorous, repeatable and auditable.

The laboratories at the UK Centre for Ecology \& Hydrology (UKCEH), Lancaster, are UKAS (United Kingdom Accreditation Service; https://www.ukas.com/, last access: 13 August 2021) accredited. UKCEH maintains a quality management system across its four sites which is ISO 9001:2015 certified.

\subsection{Results to date}

The data collected within the field survey have been analysed extensively, and the results and associated uncertainties are publicly available via GMEP (2021). One benefit of the structured sampling approach is that the "Wider Wales" control sample provides an unbiased national assessment of stock and condition of common habitats including woodland, soils, small streams and ponds. The same approach has been used for reporting on stock and condition of British ecosystems since 1978 by the UK Centre for Ecology \& Hydrology through the UKCEH Countryside Survey programme (http://www.countrysidesurvey.org.uk/, last access: $13 \mathrm{Au}-$ gust 2021) (Emmett and GMEP team, 2017). By following the same approach for selecting sites and capturing data in the field, GMEP results can be linked to past trends to put the current observations into context. This has many benefits for interpretation of results. For example, a result of "no change" (based on a comparison between GMEP and UKCEH Countryside Survey data) could be positive if it indicates a longterm decline has now been halted, but it could be negative if a previously reported improvement was now stalled (Emmett and GMEP team, 2017). The key results were reported to the Welsh Government as outlined below. Beyond this, additional work has also been carried out in several areas. Results from the field survey are also complemented by outputs from other parts of GMEP, such as modelling (for example, Emmet et al., 2017).

\subsection{Key findings as reported to Welsh Government}

Key findings were reported to the Welsh Government, alongside modelling and other outputs, in a 2017 report (Emmett and GMEP team, 2017) and online (https://www.gmep. wales). A brief summary of some of these findings, as reported in 2017, is presented as follows. In terms of biodiversity and habitat condition of land in Wales, high-quality habitat plant indicator species (positive Common Standards Monitoring (CSM) species; JNCC, 2021) were found to be either stable or improving for arable, improved land, broadleaved woodland and habitat land (land not in the former three categories; mostly neutral grassland and upland habitat types). The condition of blanket bogs is improving, as is the condition of purple moor grass and rush pasture, which are two priority habitats (Maddock, 2008). These habitats have been targeted for improvement for many years, and many actions have been undertaken to support their recovery. The relative importance of restoration practices, pollution reduction, climate and/or rainfall changes still need to be explored. Initial analysis also suggests a recent increase in the area of blanket bog and montane habitats (Emmett and GMEP team, 2017).

GMEP also identified a set of concerns in some national trends. One such concern is the lack of woodland creation, contrary to the ambitious targets of the Welsh Government (Emmett and GMEP team, 2017). While the mean patch size of habitat, including woodland, was found to have increased over the last 30 years, no change was detected in the area of small woodlands $(<0.5 \mathrm{ha})$. The small amount of area planted within the Glastir scheme by 2017 (3923 ha) is within the variability of the GMEP sample. Such small woodlands are not currently captured by the National Forest Inventory (Forest Research, 2020) and are the woodlands most likely to be affected by Glastir (Emmett and GMEP team, 2017). This does not appear to reflect the targets for expansion of woodlands set by the Welsh Government nor exploit the multiple benefits woodlands can bring for biodiversity, carbon sequestration and water regulation. In fact, this lack of progress, combined with increased agricultural activity, has led to an increase in greenhouse gas emissions in Wales (Committee on Climate Change, 2018). However, there has been an increase in plant species indicative of good condition in large broadleaved woodlands over the last 10 years, suggesting improved management of existing sites (Emmett and GMEP team, 2017).

Regarding soils, topsoil carbon has been stable or has increased in woodland and improved land soils over the last 30 years. Across all land cover types, overall topsoil has become less acidic over the last 3 decades, with the most likely reason being the large reductions of acidifying pollutants; emission and deposition of acidifying pollutants across the UK peaked in the 1970s. Recently, a small increase in the acidity of topsoil in improved land has been observed. This may be due to the long-standing decline in lime use combined with continued fertiliser use. A recent loss of topsoil 
carbon in habitat land has also been observed, driven primarily by a reduction in carbon concentration in acid grassland and heathland. This trend is currently being investigated further by UKCEH through targeted resampling of soils on acid grassland and heathland sites (Emmett and GMEP team, 2017).

Concerning freshwaters, over the last 20 years, new analyses of small stream data from Natural Resources Wales show an ongoing improvement in invertebrate diversity and nutrient status (Natural Resources Wales, 2016). GMEP sampling of headwater streams indicates more than $80 \%$ have high diversity according to invertebrate indicators. There are an estimated 9500 to $16000 \mathrm{~km}$ of headwater streams in Wales, and they are a priority conservation habitat for a range of characteristic plant and animal species. In terms of livestock, $55 \%$ of small streams were found to be freely accessible. This increases the risk of damage to banks and associated raised sediment levels and increases the risk of phosphorus and pathogen levels. The latter has implications for contamination of shellfish beds, human health and recreation. It should be noted that some access for stock is essential for exposedriver-sediment-specialist invertebrates (Emmett and GMEP team, 2017).

Only $13 \%$ of ponds sampled in GMEP were judged to be in good ecological condition. Ponds are important to the Welsh landscape, because they provide characteristic habitat and biota and support two-thirds of all freshwater species (Freshwater Habitat Trust, 2021). They act as stepping stones for biota to disperse over wide distances while also providing refuges for wildlife. They are also priority habitats under the EU habitats directive (Maddock, 2008). There is a substantial amount of pond habitat in Wales, around 57800 ponds in total. Further analysis is needed to identify the cause of this poor condition which could include poor creation practice, lag time after pond creation, runoff from adjacent fields, etc. Whilst pond numbers are high, their ecological value seems in question considering the low number in good condition. Better advice concerning their creation and management appears to be needed (Emmett and GMEP team, 2017).

\subsection{Additional published work to date}

The breadth and quantity of data available from the field survey offers many opportunities for potential analyses, as evidenced by work undertaken since the end of the field survey in 2016. Data have been used to investigate vegetation species trends along linear features, incorporating GMEP data with those from the UKCEH Countryside Survey 1990-2007 (Smart et al., 2017). Results indicated a continuation of a trend towards increased shading and woody cover. Furthermore, data from GMEP vegetation quadrats have been combined with plant trait databases and satellite imagery to map net primary productivity across Wales (Tebbs et al., 2017). GMEP vegetation data have also provided a national benchmark against which to assess bias in the con- temporary National Plant Monitoring Scheme (Pescott et al., 2019). Similarly, GMEP pollinator surveys have provided a national benchmark by which to assess the value of Wales' salt marshes for bees (Davidson et al., 2020). More recently, GMEP data permitted the most comprehensive assessment of pollinator abundance across Wales' habitats to date, revealing key roles for woodlands, woody linear features and croplands (Alison et al., 2021). Maskell et al. (2019) combined multiple strands of GMEP data to understand how species richness is distributed across landscapes, exploring relationships between land-use intensity, habitat heterogeneity and species richness of multiple taxa in order to map and monitor high nature value (HNV) farmland.

GMEP data have been used to investigate the quality and value of landscapes in Wales as a whole, focusing on how different landscapes are valued by the public, as well as transferring the methods to landscapes in Iceland (Swetnam et al., 2017; Swetnam and Korenko, 2019; Swetnam and Tweed, 2018). GMEP mapping data have also been used for accuracy assessment of land cover maps, produced using satellite imagery (Carrasco et al., 2019).

A range of different work concerning soils has been undertaken since 2016. This includes a consideration of differences in soil physico-chemical properties across habitats and relative to known thresholds for supporting habitat function (Seaton et al., 2020a). Several key soil properties, such as carbon, nitrogen and $\mathrm{pH}$, were found to be strongly correlated across soils and can be used to create a soils classification. Soil analyses were complemented by microbiological measurements from DNA metabarcoding of specific target genes, deposited with the European Nucleotide Archive (ENA) at EMBL-EBI (Environment Centre Wales (Bangor University), 2016a-c). These results, and the methods used to determine them are presented in George et al. (2019a), where it was demonstrated that soil microbial and soil animal taxa respond differently to changes in land use and soil type. Animal richness was governed by intensive land use and unaffected by soil properties, while microbial richness was driven by environmental properties across land uses. The efficacy of $18 \mathrm{~S}$ and ITS1 barcodes in capturing fungal biological and functional diversity has been compared, revealing barcode biases that influenced metrics of functional but not biological diversity (George et al., 2019b). Investigations of bacterial functional groups in the $16 \mathrm{~S}$ marker gene dataset showed changes in sulfate-reducing bacterial communities across land uses, with highest richness in grasslands (George et al., 2020).

Soil meso-fauna have been described by George et al. (2017), explaining how broad soil meso-fauna groups differed among disparate habitats, with abundances being lowest in arable sites overall, and Collembola and predatory mites being lower in uplands.

In terms of soil particle size, soil textural heterogeneity was found to be positively linked to bacterial richness for the first time (Seaton et al., 2020b), but fungal richness was 
not directly impacted by soil texture. Both bacterial and fungal community compositions were impacted by the textural composition of the soil. Data from GMEP have even contributed to international studies of the macroecology of soil bacterial communities (Ramirez et al., 2018).

Soil water repellency results are presented in Seaton et al. (2019). They found that soil water repellency affected $92 \%$ of soils at a national scale across Wales and that plant and soil microbial community composition strongly influenced repellency. Repellency is associated with bypass flow in soils, which can transmit pollutants faster to groundwater. However, Seaton et al. (2019) proposed a mechanism whereby soil biota mediated the association between repellency and many physico-chemical stresses.

Work to date focusing on the freshwater data has concentrated on diatoms (Jones et al., 2017). Various data analysis techniques were used to explore how indices based on diatom assemblages (related to eutrophication and siltation), diatom species, the traits motility and nutrient affinity responded to a gradient of percentage cover of fine sediment.

\section{Data availability}

The datasets have been assigned digital object identifiers (DOIs), and users of the data must reference the data as follows:

- Botham et al. (2020). Insect pollinator and flower data from the Glastir Monitoring and Evaluation Programme, Wales, 2013-2016. Natural Environment Research Council (NERC) Environmental Information Data Centre. https://doi.org/10.5285/3c8f4e46bf6c-4ea1-9340-571fede26ee8 (Botham et al., 2020);

- Keith et al. (2019). Topsoil meso-fauna data from the Glastir Monitoring and Evaluation Programme, Wales 2013-2014. https://doi.org/10.5285/1c5cf3172f03-4fef-b060-9eccbb4d9c21 (Keith et al., 2019);

- Lebron et al. (2020). Topsoil particle size distribution from the Glastir Monitoring and Evaluation Programme, Wales 2013-2016. https://doi.org/10.5285/d6c3cc3c-a7b7-48b2-9e61d07454639656 (Lebron et al., 2020);

- Maskell et al. (2020). Landscape and habitat area data from the Glastir Monitoring and Evaluation Programme, Wales 2013-2016. https://doi.org/10.5285/82c63533-529e-47b9-8e7851b27028cc7f (Maskell et al., 2020a);

- Maskell et al. (2020). Landscape linear feature data from the Glastir Monitoring and Evaluation Programme, Wales 2013-2016. https://doi.org/10.5285/f481c6bf-5774-4df8-8776c4d7bf059d40 (Maskell et al., 2020b);
- Maskell et al. (2020). Landscape point feature data from the Glastir Monitoring and Evaluation Programme, Wales 2013-2016. https://doi.org/10.5285/9f8d9cc6b552-4c8b-af09-e92743cdd3de (Maskell et al., 2020c);

- Robinson et al. (2019). Topsoil physico-chemical properties from the Glastir Monitoring and Evaluation Programme, Wales 2013-2016. https://doi.org/10.5285/0fa51dc6-1537-4ad6-9d06e476c137ed09 (Robinson et al., 2019);

- Scarlett et al. (2020). Pond quality metrics from the Glastir Monitoring and Evaluation Programme, Wales 2013-2016. https://doi.org/10.5285/687b38d32278-41a0-9317-2c7595d6b882 (Scarlett et al., 2020b);

- Scarlett et al. (2020). Headwater stream quality metrics from the Glastir Monitoring and Evaluation Programme, Wales 2013-2016. NERC Environmental Information Data Centre. https://doi.org/10.5285/e305fa80-3d38-4576-beeff6546fad5d45 (Scarlett et al., 2020a);

- Siriwardena et al. (2020). Bird counts from the Glastir Monitoring and Evaluation Programme, Wales 20132016. NERC Environmental Information Data Centre. https://doi.org/10.5285/31da0a94-62be-47b3-b76e4bdef3037360 (Siriwardena et al., 2020);

- Smart et al. (2020). Vegetation plot data from the Glastir Monitoring and Evaluation Programme, Wales 2013-2016. https://doi.org/10.5285/71d3619c4439-4c9e-84dc-3ca873d7f5cc (Smart et al., 2020);

The datasets are available in non-proprietary formats from the UKCEH Environmental Information Data Centre Catalogue (https://eip.ceh.ac.uk/data, last access: $13 \mathrm{Au}-$ gust 2021). Datasets are provided under the terms of the Open Government Licence (http://www.nationalarchives. gov.uk/doc/open-government-licence/version/3/, last access: 13 August 2021). The metadata are stored in the ISO 19115 (2003) schema (International Organization for Standardization, 2015) in the UK Gemini 2.3 profile (UK GEMINI, https://www.agi.org.uk/ agi-groups/standards-committee/uk-gemini/40-gemini/ 1037-uk-gemini-standard-and-inspire-implementing-rules, last access: 13 August 2021).

Users of the datasets will find the following field handbooks useful when reusing data (supplied as supporting documentation with the datasets): Landscape mapping (Maskell et al., 2016a, b), Vegetation and soils (Smart et al., 2016), Freshwaters (O'Hare et al., 2013), Birds (Siriwardena and Taylor, 2014) and Pollinators (Botham et al., 2014). 


\section{Conclusions}

The data recorded during the GMEP field survey provide an invaluable resource for studying the environment in Wales. The data were collected in a statistically robust and quality controlled manner; follow standard, repeatable methods; and cover wide spatial scales. Complemented by data from the UKCEH Countryside Survey of Great Britain, trends across Wales can be assessed, dating back to 1978. As a consequence of this, the data present a unique opportunity for inclusion in a wide range of analyses and models. Data gathered within the field survey are complemented by the additional information arising from the programme of GMEP as a whole, which includes qualitative data such as photographs, social science farmer practice survey data, modelling outputs and assessments of historic features.

The intention is that a repeat survey will be undertaken in the near future in order to provide the opportunity to analyse changes in the countryside (see https://erammp.wales/en, last access: 13 August 2021, for the latest updates).

Combining the field datasets with information from thirdparty sources would provide additional opportunities for more extensive analyses. High-level questions and tasks deserving further analysis include investigations of drivers of change, such as looking at evidence for change in the stock and condition of individual broad habitats; exploring the reasons for the finding of decreased topsoil carbon in habitat land and the increased acidity in improved land; and investigating how the spatial and temporal trends observed in soil, vegetation, pollinators, birds, and water are linked. Also of interest would be how climate change and air pollution signals might be distinguished from changes in land management, linked to economic drivers (Emmett and GMEP team, 2017).

Of wider interest to the public might be work to identify the relationship between the area and condition of our natural resources as indicated by the GMEP survey and the health and well-being of the wider population.

The GMEP data could be exploited to provide an assessment of the general condition of designated lands benchmarked against average national trends (for example, to determine whether soil condition above or below that of the national average). This could assist towards more integrated working for new regulatory frameworks and incentive schemes.

It is expected that the GMEP data, and also modelling and knowledge gained during the programme, will be invaluable when it comes to tackling new issues such as the UK's withdrawal from the European Union, particularly in assisting the Welsh Government in developing new regulatory frameworks and incentive schemes.

Author contributions. CMW and JA drafted the manuscript and created the figures, with contributions from all co-authors. Authors were each involved in the following areas of work: data management, CMW and JA; vegetation and habitats, SMS, LCM and LRN; butterflies, RH; birds, GMS; pollinators, MSB; chemical analysis of samples, PK; soils, DAR, PBLG, FMS, AMK and IL; freshwaters, FE and PS; and integrated data analyses, SJ.

PAH was responsible for the statistical design of the survey and the project informatics strategy. RAG and $A B$ managed the field surveys. BW managed the GMEP project and BAE was the principal investigator. JS oversaw the project.

Competing interests. The authors declare that they have no conflict of interest.

Disclaimer. Publisher's note: Copernicus Publications remains neutral with regard to jurisdictional claims in published maps and institutional affiliations.

Acknowledgements. We thank the approximately 60 members of the GMEP field-survey teams who contributed to collecting all the data. We thank the soil processing teams, Gaynor Barrett, Heather Carter, Simon Creer, Beverley Dodd, Andrew Fitton, Claudia Giampieri, Rob Griffiths, Steve Hughes, Alex Hunt, Davey Jones, Delphine Lallias, Rachel Marshall, David Nuñez, Manisha Patel, Gloria Pereira, Binoti Tanna and Nicola Thompson. For diatom identification, we thank Bowburn Consultancy, Durham (http: //www.bowburn-consultancy.co.uk/, last access: 13 August 2021), and for freshwater invertebrate identification, we thank APEM Ltd (https://www.apemltd.co.uk/, last access: 13 August 2021).

We thank the bird and pollinator survey teams, George Tordoff, Rachel Taylor and Mike Edwards. For data management, we thank Shaun Astbury, Mike Brown, Jane Hall, Katrina Sharps, John Watkins and Simon Wright. For additional survey elements regarding landscapes and historic features, we thank Ruth Swetnam, Ian Halfpenney and teams. For botanical quality assurance, we thank Hilary Wallace of Ecological Surveys (Bangor) Ltd.

We thank Anthea Owen for obtaining permissions to survey from approximately 1500 landowners across Wales. We thank all of the landowners who granted permission to survey on their land, without which the survey could not have taken place.

We also thank the GMEP Stakeholder Group for valuable advice and support.

We thank two anonymous reviewers for their helpful comments which have improved the article considerably.

Financial support. The research was funded by the Welsh Government through the Glastir Monitoring and Evaluation Programme (GMEP) (contract reference no. C147/2010/11) and NERC/UK Centre for Ecology \& Hydrology (UKCEH projects nos. NEC04780, NEC05371, and NEC05782).

Review statement. This paper was edited by David Carlson and reviewed by two anonymous referees. 


\section{References}

Alison, J., Botham, M., Maskell, L. C., Garbutt, A., Seaton, F. M., Smart, S. M., Thomas, A., Williams, B., Wood, C. M., and Emmett, B. A.: Woodland, woody linear features and cropland underpin pollinator abundance in improved grassland landscapes, TBA, in preparation, 2021.

Avery, B. W. and Bascomb, C. L.: Soil survey laboratory methods, Rothamsted Experimental Station, Harpenden (UK), 1974.

Botham, M., Peyton, J., Edwards, M., Tordoff, G., Hobson, R., and Roy, D.: GMEP Pollinator Protocol, NERC Centre for Ecology \& Hydrology, Bangor, 2014.

Botham, M., Peyton, J., Tordoff, G., Edwards, M., Alison, J., Astbury, S., Burden, A., Emmett, B. A., Garbutt, A., Henrys, P., Owen, A., Smart, S. M., Sharps, K., Williams, B., and Wood, C. M.: Insect pollinator and flower data from the Glastir Monitoring and Evaluation Programme, Wales, 2013-2016, NERC Environmental Information Data Centre, https://doi.org/10.5285/3c8f4e46-bf6c-4ea1-9340571fede26ee8, 2020.

Brereton, T. M., Cruickshanks, K. L., Risely, K., Noble, D. G., and Roy, D. B.: Developing and launching a wider countryside butterfly survey across the United Kingdom, J. Insect Conserv., 15, 279-290, https://doi.org/10.1007/s10841-010-9345-8, 2011.

Brereton, T. M., Botham, M. S., Middlebrook, I., Randle, Z., D., N., Harris, S., Dennis, E. B., Robinson, A. E., Peck, K., and Roy, D. B.: United Kingdom Butterfly Monitoring Scheme report for 2018, Centre for Ecology \& Hydrology, Butterfly Conservation, British Trust for Ornithology and Joint Nature Conservation Committee, available at: https://ukbms.org/sites/default/files/ downloads/UKBMSButterflyAnnualReport2018Lowres.pdf (last access: 13 August 2021), 2019.

Bunce, R. G. H.: Ecological survey of Britain, Institute of Terrestrial Ecology, Cambridge, 74-75 pp., 1979.

Bunce, R. G. H. and Smith, R. S.: An ecological survey of Cumbria, Cumbria County Council and Lake District Special Planning Board, Kendal, available at: http://nora.nerc.ac.uk/id/eprint/ 4313/1/Bunce1978EcolSurveyCumbria.pdf (last access: 13 August 2021), 1978.

Bunce, R. G. H., Barr, C. J., Clarke, R. T., Howard, D., and Scott, A.: ITE Land Classification of Great Britain 2007, NERC Environmental Information Data Centre, $\quad$ https://doi.org/10.5285/5f0605e4-aa2a-48ab-b47cbf5510823e8f, 2007.

Carey, P. D., Wallis, S., Chamberlain, P. M., Cooper, A., Emmett, B. A., Maskell, L. C., McCann, T., Murphy, J., Norton, L. R., Reynolds, B., Scott, W. A., Simpson, I. C., Smart, S. M., and Ullyett, J. M.: Countryside Survey: UK Results from 2007, NERC/Centre for Ecology \& Hydrology, Lancaster, available at: http://nora.nerc.ac.uk/id/eprint/5191/1/ N005191CRUKResults.pdf (last access: 13 August 2021), 2008.

Carrasco, L., O'Neil, A. W., Morton, R. D., and Rowland, C. S.: Evaluating combinations of temporally aggregated Sentinel-1, Sentinel-2 and Landsat 8 for land cover mapping with Google Earth Engine, Remote Sens.-Basel, 11, 288, https://doi.org/10.3390/rs11030288, 2019.

Committee on Climate Change: Reducing UK Emissions: 2018 Progress Report to Parliament, Committee on Climate Change, available at: http://www.theccc.org.uk/publications (last access: 13 August 2021), 2018.

Davidson, K. E., Fowler, M. S., Skov, M. W., Forman, D., Alison, J., Botham, M., Beaumont, N., and Griffin, J. N.: Grazing reduces bee abundance and diversity in saltmarshes by suppressing flowering of key plant species, Agriculture, Ecosystems \& Environment, 291, 106760, https://doi.org/10.1016/j.agee.2019.106760, 2020.

DEFRA: Joint Code of Practice for Research (JCoPR), available at: https://assets.publishing.service.gov.uk/government/ uploads/system/uploads/attachment_data/file/413154/

pb13725-research-code-practice.pdf (last access: 13 August 2021), 2015.

Emmett, B., Frogbrook, Z., Chamberlain, P., Griffiths, R., Pickup, R., Poskitt, J., Reynolds, B., Rowe, E., Spurgeon, D., and Rowland, P.: CS Technical Report No. 3/07: Soils Manual, Centre for Ecology \& Hydrology Wallingford, UK, available at: http://nora.nerc.ac.uk/id/eprint/5201/1/CS_UK_2007_TR3\% 5B1\%5D.pdf (last access: 13 August 2021), 2008.

Emmett, B., Abdalla, M., Anthony, S., Astbury, S., August, T., Barrett, G., Beckmann, B., Biggs, J., Botham, M., and Bradley, D.: Glastir Monitoring \& Evaluation Programme. Second year annual report, UK Centre for Ecology \& Hydrology, Bangor, available at: http://nora.nerc.ac.uk/id/eprint/512331/1/N512331CR. pdf (last access: 13 August 2021), 2015.

Emmett, B. A., Reynolds, B., Chamberlain, P. M., Rowe, E., Spurgeon, D., Brittain, S. A., Frogbrook, Z., Hughes, S., Lawlor, A. J., Poskitt, J., Potter, E., Robinson, D. A., Scott, A., Wood, C., and Woods, C.: Countryside Survey: Soils Report from 2007, Centre for Ecology \& Hydrology, Wallingford, UK, available at: http://nora.nerc.ac.uk/9354/ (last access: 13 August 2021), 2010.

Emmett, B. E. and GMEP team: Glastir Monitoring \& Evaluation Programme. First Year Annual Report to Welsh Government (Contract reference: C147/2010/11), NERC/Centre for Ecology \& Hydrology, Bangor, 442 pp., available at: http://nora.nerc.ac. uk/id/eprint/506219/14/N506219CRX.pdf (last access: 13 August 2021), 2014.

Emmett, B. E. and GMEP team: Glastir Monitoring \& Evaluation Programme. Final Report to Welsh Government - Executive Summary (Contract reference: C147/2010/11), NERC/Centre for Ecology \& Hydrology, Bangor, available at: http://nora.nerc.ac. uk/id/eprint/518194/1/N518194CR.pdf (last access: 13 August 2021), 2017.

Environment Centre Wales (Bangor University): Glastir Monitoring \& Evaluation Programme (2012-2016) sequencing data, available at: https://www.ebi.ac.uk/ena/browser/view/PRJEB27883 (last access: 25 January 2021), 2016 .

Environment Centre Wales (Bangor University): Glastir Monitoring $\&$ Evaluation Programme data from 18 S sequencing, available at: https://www.ebi.ac.uk/ena/browser/view/PRJEB28067 (last access: 25 January 2021), 2016 b.

Environment Centre Wales (Bangor University): Glastir Monitoring \& Evaluation Programme sequencing data 2012-2016: ITS1 data, available at: https://www.ebi.ac.uk/ena/browser/view/ PRJEB28028 (last access: 25 January 2021), 2016 c.

Esri: ArcMap, World Imagery Sources: Esri, DigitalGlobe, GeoEye, i-cubed, USDA FSA, USGS, AEX, Getmapping, Aerogrid, IGN, IGP, swisstopo, and the GIS User Community, Map was created using $\operatorname{ArcGIS}^{\circledR}$ software by Esri, ArcGIS ${ }^{\circledR}$ and $\operatorname{ArcMap}^{\mathrm{TM}}$ are 
the intellectual property of Esri and are used herein under license, Copyright $\odot$ Esri, All rights reserved. For more information about Esri ${ }^{\circledR}$ software, please visit http://www.esri.com (last access: 13 August 2021), 2021.

Forest Research: National Forest Inventory, available at: https://www.forestresearch.gov.uk/tools-and-resources/ national-forest-inventory/ (last access: 4 November 2020), 2020.

Fourtanier, E. and Kociolek, J. P.: Catalogue of the diatom genera, Diatom Res., 14, 1-190, https://doi.org/10.1080/0269249X.1999.9705462, 1999.

Freshwater Habitat Trust: Ponds, available at: https: //freshwaterhabitats.org.uk/habitats/pond/ (last access: 22 January 2021), 2021.

Gee, G. W. and Or, D.: 2.4 Particle-size analysis, in: Methods of soil analysis: Part 4 physical methods, edited by: Dane, J. H. and Topp, C. G., Wiley, 255-293, 2002.

George, P. B. L., Keith, A. M., Creer, S., Barrett, G. L., Lebron, I., Emmett, B. A., Robinson, D. A., and Jones, D. L.: Evaluation of mesofauna communities as soil quality indicators in a nationallevel monitoring programme, Soil Biol. Biochem., 115, 537-546, https://doi.org/10.1016/j.soilbio.2017.09.022, 2017.

George, P. B. L., Lallias, D., Creer, S., Seaton, F. M., Kenny, J. G., Eccles, R. M., Griffiths, R. I., Lebron, I., Emmett, B. A., and Robinson, D. A.: Divergent national-scale trends of microbial and animal biodiversity revealed across diverse temperate soil ecosystems, Nat. Commun., 10, 1-11, https://doi.org/10.1038/s41467-019-09031-1, 2019a.

George, P. B. L., Creer, S., Griffiths, R. I., Emmett, B. A., Robinson, D. A., and Jones, D. L.: Primer and Database Choice Affect Fungal Functional but Not Biological Diversity Findings in a National Soil Survey, Frontiers in Environmental Science, 7, 173, https://doi.org/10.3389/fenvs.2019.00173, 2019 b.

George, P. B. L., Coelho, K. P., Creer, S., Lebron, I., Robinson, D. A., and Jones, D. L.: Decoupled richness of generalist anaerobes and sulphate-reducing bacteria is driven by $\mathrm{pH}$ across land uses in temperate soils, Eur. J. Soil Sci., 1-12, https://doi.org/10.1111/ejss.13040, 2020.

GMEP: Glastir Monitoring and Evaluation Programme, Data and Findings, Centre for Ecology and Hydrology, available at: https: //gmep.wales/data-findings (last access: 9 July 2021), 2021.

Harris, S., Massimino, D., Gillings, S., Eaton, M., Noble, D., Balmer, D., Procter, D., Pearce-Higgins, J., and Woodcock, P.: The breeding bird survey 2017, British Trust for Ornithology, available at: https://www.bto.org/sites/default/files/ bbs-report-2017.pdf (last access: 13 August 2021), 2018.

Harris, S., Massimino, D., Eaton, M., Gillings, S., Noble, D., Balmer, D., Pearce-Higgins, J., and Woodcock, P.: The Breeding Bird Survey 2018, BTO Research Report 717, British Trust for Ornithology, Thetford, 2019.

Hartley, B.: An atlas of British diatoms, Balogh Scientific Books, 1996.

Hofmann, G., Werum, M., and Lange-Bertalot, H.: Diatomeen im Süßwasser-Benthos von Mitteleuropa: Bestimmungsflora Kieselalgen für die ökologische Praxis; über 700 der häufigsten Arten und ihrer Ökologie, Gantner, 2011.

Howard, S.: A guide to monitoring the ecological quality of ponds and canals using PSYM, PSYM Method, Freshwater Habitats Trust, available at: https://freshwaterhabitats.org.uk/wp-content/
uploads/2013/09/NPMN_PSYM_MANUAL_July09.pdf (last access: 13 August 2021), 2002.

Jackson, D.: Guidance on the Interpretation of the Biodiversity Broad Habitat Classification (Terrestrial and Freshwater Types): Definitions and the Relationship with Other Habitat Classifications (JNCC Report, No 307), Joint Nature Conservation Committee, available at: http://jncc.defra.gov.uk/page-2433, 73 pp., 2000.

JNCC: Common Standards Monitoring, Joint Nature Conservation Committee, available at: https://jncc.gov.uk/our-work/ common-standards-monitoring/ (last access: 9 July 2021), 2021.

Jones, J. I., Douthwright, T. A., Arnold, A., Duerdoth, C. P., Murphy, J. F., Edwards, F. K., and Pretty, J. L.: Diatoms as indicators of fine sediment stress, Ecohydrology, 10, e1832, https://doi.org/10.1002/eco.1832, 2017.

Keith, A. M., Astbury, S., Dodd, B. A., Emmett, B. A., Fitton, A., Garbutt, A., George, P., Marshall, R., Robinson, D. A., Williams, B., and Wood, C. M.: Topsoil meso-fauna data from the Glastir Monitoring and Evaluation Programme, Wales 2013-2014, UK Centre for Ecology \& Hydrology, https://doi.org/10.5285/1c5cf317-2f03-4fef-b0609eccbb4d9c21, 2019.

Kelly, M. G., Cazaubon, A., Coring, E., Dell'Uomo, A., Ector, L., Goldsmith, B., Guasch, H., Hürlimann, J., Jarlman, A., Kawecka, B., Kwandrans, J., Laugaste, R., Lindstrøm, E. A., Leitao, M., Marvan, P., Padisák, J., Pipp, E., Prygiel, J., Rott, E., Sabater, S., van Dam, H., and Vizinet, J.: Recommendations for the routine sampling of diatoms for water quality assessments in Europe, J. Appl. Phycol., 10, 215, https://doi.org/10.1023/a:1008033201227, 1998.

Krammer, K. and Lange-Bertalot, H.: Die Süsswasserflora von Mitteleuropa 2: Bacillariophyceae. 1 Teil: Naviculaceae, Gustav Fischer Verlag, Stuttgart, 1986.

Krammer, K. and Lange-Bertalot, H.: Die Süßwasserflora von Mitteleuropa, II: 2. Bacillariophyceae. Teil 2: Bacillariaceae, Epithemiaceae, Surirellaceae, 2te Auflage, mit einem neuen Anhang, Gustav Fischer Verlag, Stuttgart, 1997.

Krammer, K. and Lange-Bertalot, H.: Die Süsswasserflora von Mitteleuropa 2: Bacillariophyceae. 3 Teil: Centrales, Fragilariaceae, Eunotiaceae, Gustav Fischer Verlag, Stuttgart, 2000.

Krammer, K. and Lange-Bertalot, H.: Süsswasserflora von Mitteleuropa 2, Bacillariophyceae. Teil 4 : Achnanthaceae. Kritische Ergänzungen zu Achnanthes s.l., Navicula s. str., Gomphonema, Spektrum Akademischer Verlag/Gustav Fischer, Heidelberg, 2004.

Lebron, I., Suarez, D. L., Amrhein, C., and Strong, J. E.: Size of Mica Domains and Distribution of the Adsorbed Na-Ca Ions, Clay. Clay Miner., 41, 380-388, https://doi.org/10.1346/ccmn.1993.0410315, 1993.

Lebron, I., Seaton, F., Barrett, G., Alison, J., Burden, A., Emmett, B. A., Garbutt, A., Robinson, D. A., Williams, B., and Wood, C. M.: Topsoil particle size distribution from the Glastir Monitoring and Evaluation Programme, Wales 2013-2016, UK Centre for Ecology \& Hydrology, https://doi.org/10.5285/d6c3cc3c-a7b7-48b29e61-d07454639656, 2020.

Maddock, A.: UK Biodiversity Action Plan; Priority Habitat Descriptions, Joint Nature Conservation Committee, available at: http://jncc.defra.gov.uk/PDF/UKBAP 
PriorityHabitatDesc-Rev2011.pdf (last access: 13 August 2021), 2008.

Maskell, L., Halfpenney, I., Norton, L., Seaton, R., Smart, S., Ewald, N., Thackray, A., and Wood, C.: GLASTIR MONITORING \& EVALUATION PROGRAMME MAPPING FIELD HANDBOOK Part 1: Habitat attributes, NERC Centre for Ecology \& Hydrology, Bangor, 2016a.

Maskell, L., Norton, L., Aspey, N., Seaton, R., Smart, S., and Wood, C.: GLASTIR MONITORING \& EVALUATION PROGRAMME MAPPING FIELD HANDBOOK Part 2: using Surveyor software, NERC Centre for Ecology \& Hydrology, Bangor, 2016 b.

Maskell, L. C., Norton, L. R., Smart, S. M., Carey, P. D., Murphy, J., Chamberlain, P. M., Wood, C. M., Bunce, R. G. H., and Barr, C. J.: Countryside Survey. Field Mapping Handbook CS Technical Report No. 1/07, Centre for Ecology \& Hydrology, Lancaster, available at: http://nora.nerc.ac.uk/5194/ (last access: 13 August 2021), 2008.

Maskell, L. C., Botham, M., Henrys, P., Jarvis, S., Maxwell, D., Robinson, D. A., Rowland, C. S., Siriwardena, G., Smart, S., Skates, J., Tebbs, E. J., Tordoff, G. M., and Emmett, B. A.: Exploring relationships between land use intensity, habitat heterogeneity and biodiversity to identify and monitor areas of High Nature Value farming, Biol. Conserv., 231, 30-38, https://doi.org/10.1016/j.biocon.2018.12.033, 2019.

Maskell, L. C., Astbury, S., Burden, A., Emmett, B. A., Garbutt, A., Goodwin, A., Henrys, P., Jarvis, S., Norton, L. R., Owen, A., Sharps, K., Smart, S. M., Williams, B., Wood, C. M., and Wright, S. M.: Landscape and habitat area data from the Glastir Monitoring and Evaluation Programme, Wales 2013-2016, UK Centre for Ecology \& Hydrology, https://doi.org/10.5285/82c63533529e-47b9-8e78-51b27028cc7f, 2020a.

Maskell, L. C., Astbury, S., Burden, A., Emmett, B. A., Garbutt, A., Goodwin, A., Henrys, P., Jarvis, S., Norton, L. R., Owen, A., Sharps, K., Smart, S. M., Williams, B., Wood, C. M., and Wright, S. M.: Landscape linear feature data from the Glastir Monitoring and Evaluation Programme, Wales 2013-2016, UK Centre for Ecology \& Hydrology, https://doi.org/10.5285/f481c6bf5774-4df8-8776-c4d7bf059d40, 2020b.

Maskell, L. C., Astbury, S., Burden, A., Emmett, B. A., Garbutt, A., Goodwin, A., Henrys, P., Jarvis, S., Norton, L. R., Owen, A., Sharps, K., Smart, S. M., Williams, B., Wood, C. M., and Wright, S. M.: Landscape point feature data from the Glastir Monitoring and Evaluation Programme, Wales 2013-2016, UK Centre for Ecology \& Hydrology, https://doi.org/10.5285/9f8d9cc6-b5524c8b-af09-e92743cdd3de, 2020c.

Morton, D., Rowland, C., Wood, C., Meek, L., Marston, C., Smith, G., Wadsworth, R., and Simpson, I.: Final Report for LCM2007 - the new UK land cover map, Technical Report No. 9/07, NERC/Centre for Ecology \& Hydrology, Wallingford, CS, available at: http://nora.nerc.ac.uk/id/eprint/14854/1/LCM2007_ Final_Report_-_vCS_Web.pdf (last access: 13 August 2021), 2011.

Murray-Bligh, J. A. D.: Procedure for collecting and analysing macroinvertebrate samples, Environment Agency, Bristol, UK, 1999.

Natural Resources Wales: State of Natural Resources Report (SoNaRR): Assessment of the Sustainable Management of Natural Resources, Technical Report, Natural Resources
Wales, available at: https://naturalresources.wales/evidenceand-data/research-and-reports/the-state-of-natural-resourcesreport-assessment-of-the-sustainable-management-of-naturalresources/?lang=en (last access: 13 August 2021), 2016.

Natural Resources Wales: State of Natural Resources Report (SoNaRR): Executive Summary, Natural Resources Wales, available at: https://cdn.cyfoethnaturiol.cymru/media/692868/ sonarr2020-executive-summary.pdf (last access: 13 August 2021), 2020.

Norton, L. R., Maskell, L. C., Smart, S. M., Dunbar, M. J., Emmett, B. A., Carey, P. D., Williams, P., Crowe, A., Chandler, K., Scott, W. A., and Wood, C. M.: Measuring stock and change in the GB countryside for policy: key findings and developments from the Countryside Survey 2007 field survey, J. Environ. Manage., 113, 117-127, https://doi.org/10.1016/j.jenvman.2012.07.030, 2012.

O'Connor, R. J.: The common birds census in the United Kingdom, Survey designs and statistical methods for the estimation of avian population trends, Biological Report, 90, 47-53, US Fish and Wildlife Service, 1990.

O’Hare, M., Garbutt, A., Edwards, F., Gunn, I., Scarlett, P., Ewald, N., and Kelly, M.: Glastir Monitoring \& Evaluation Programme FIELD HANDBOOK Freshwater, NERC Centre for Ecology \& Hydrology, Bangor, 2013.

Ordnance Survey: Boundary-Line, available at: https: //www.ordnancesurvey.co.uk/business-government/ products/boundaryline?_ga=2.4625139.1114143439. 1612358349-1893430525.1612358349 (last access: 3 February 2021), 2020.

Pescott, O. L., Walker, K. J., Harris, F., New, H., Cheffings, C. M., Newton, N., Jitlal, M., Redhead, J., Smart, S. M., and Roy, D. B.: The design, launch and assessment of a new volunteer-based plant monitoring scheme for the United Kingdom, PloS one, 14, e0215891, https://doi.org/10.1371/journal.pone.0215891, 2019.

Pollard, E.: A method for assessing changes in the abundance of butterflies, Biol. Conserv., 12, 115-134, https://doi.org/10.1016/0006-3207(77)90065-9, 1977.

Potapova, M. and Hamilton, P. B.: Morphological and ecological variation within the Achnanthidium minutissimum (Bacillariophyceae) species complex 1, J. Phycol., 43, 561-575, https://doi.org/10.1111/j.1529-8817.2007.00332.x, 2007.

Ramirez, K. S., Knight, C. G., De Hollander, M., Brearley, F. Q., Constantinides, B., Cotton, A., Creer, S., Crowther, T. W., Davison, J., and Delgado-Baquerizo, M.: Detecting macroecological patterns in bacterial communities across independent studies of global soils, Nat. Microbiol., 3, 189-196, https://doi.org/10.1038/s41564-017-0062-x, 2018.

River Habitat Survey: River Habitat Survey, available at: http: //www.riverhabitatsurvey.org/ (last access: 3 February 2021), 2021.

Robinson, D. A., Astbury, S., Barrett, G., Burden, A., Carter, H., Emmett, B. A., Garbutt, A., Giampieri, C., Hall, J., Henrys, P., Hughes, S., Hunt, A., Jarvis, S., Jones, D. L., Keenan, P., Lebron, I., Nunez, D., Owen, A., Patel, M., Pereira, M. G., Seaton, F., Sharps, K., Tanna, B., Thompson, N., Williams, B., and Wood, C. M.: Topsoil physico-chemical properties from the Glastir Monitoring and Evaluation Programme, Wales 2013-2016, UK Centre for Ecology \& Hydrology, https://doi.org/10.5285/0fa51dc61537-4ad6-9d06-e476c137ed09, 2019. 
Round, F. E., Crawford, R. M., and Mann, D. G.: Diatoms: biology and morphology of the genera, Cambridge University Press, 2007.

Scarlett, P., Edwards, F., Astbury, S., Burden, A., Carter, H., Emmett, B. A., Garbutt, A., Henrys, P. A., Keenan, P., Owen, A., Sharps, K., Williams, B., and Wood, C. M.: Headwater stream quality metrics from the Glastir Monitoring and Evaluation Programme, Wales 2013-2016, UK Centre for Ecology \& Hydrology, https://doi.org/10.5285/e305fa80-3d38-4576beef-f6546fad5d45, 2020a.

Scarlett, P., Edwards, F., Astbury, S., Burden, A., Carter, H., Emmett, B. A., Garbutt, A., Henrys, P. A., Keenan, P., Owen, A., Sharps, K., Williams, B., and Wood, C. M.: Pond quality metrics from the Glastir Monitoring and Evaluation Programme, Wales 2013-2016, UK Centre for Ecology \& Hydrology, https://doi.org/10.5285/687b38d3-2278-41a0-93172c7595d6b882, 2020b.

Seaton, F. M., Jones, D. L., Creer, S., George, P. B. L., Smart, S. M., Lebron, I., Barrett, G., Emmett, B. A., and Robinson, D. A.: Plant and soil communities are associated with the response of soil water repellency to environmental stress, Sci. Total Environ., 687, 929-938, https://doi.org/10.1016/j.scitotenv.2019.06.052, 2019.

Seaton, F. M., Barrett, G., Burden, A., Creer, S., Fitos, E., Garbutt, A., Griffiths, R. I., Henrys, P., Jones, D. L., Keenan, P., and Keith, A.: Soil health cluster analysis based on national monitoring of soil indicators, Eur. J. Soil Sci., 1-16, https://doi.org/10.1111/ejss.12958, 2020a.

Seaton, F. M., George, P. B. L., Lebron, I., Jones, D. L., Creer, S., and Robinson, D. A.: Soil textural heterogeneity impacts bacterial but not fungal diversity, Soil Biol. Biochem., 144, 107766, https://doi.org/10.1016/j.soilbio.2020.107766, 2020 b.

Siriwardena, G. M. and Taylor, R. C.: GMEP Bird Survey Field Handbook, British Trust for Ornithology, Bangor, 2014.

Siriwardena, G. M., Taylor, R. M., Norfolk, D., Jones, K., Alison, J., Astbury, S., Burden, A., Emmett, B. A., Garbutt, A., Henrys, P., Owen, A., Smart, S. M., Sharps, K., Williams, B., and Wood, C. M.: Bird counts from the Glastir Monitoring and Evaluation Programme, Wales 2013-2016, UK Centre for Ecology \& Hydrology, https://doi.org/10.5285/31da0a94-62be-47b3b76e-4bdef3037360, 2020.

Smart, S., Maskell, L. C., Norton, L. R., Bunce, R. G. H., Barr, C. J., Robinson, D. A., Barrett, G., Wood, C. M., Emmett, B. A., Jones, D., Keith, A., Lallias, D., Rawlins, B., and GMEP survey teams: GLASTIR MONITORING \& EVALUATION PROGRAMME VEGETATION AND SOIL FIELD HANDBOOK, NERC Centre for Ecology \& Hydrology, Bangor, 2016.

Smart, S. M., Henrys, P. A., Norton, L. R., Wallace, H., Wood, C. M., Williams, B., and Bunce, R. G. H.: Changes in the frequency of common plant species across linear features in Wales from 1990 to 2016: implications for potential delivery of ecosystem services, New Journal of Botany, 7, 112-124, https://doi.org/10.1080/20423489.2017.1408190, 2017.

Smart, S. M., Astbury, S., Burden, A., Emmett, B. A., Garbutt, A., Henrys, P., Maskell, L. C., Owen, A., Sharps, K., Wallace, H., Williams, B., and Wood, C. M.: Vegetation plot data from the Glastir Monitoring and Evaluation Programme, Wales 2013-2016, UK Centre for Ecology \& Hydrology, https://doi.org/10.5285/71d3619c-4439-4c9e-84dc3ca873d7f5cc, 2020.
Southwood, T.: Ecological methods, Chapman and Hall, London, 1994.

Swetnam, R. D. and Tweed, F. S.: A tale of two landscapes: Transferring landscape quality metrics from Wales to Iceland, Land Use Policy, 76, 565-576, https://doi.org/10.1016/j.landusepol.2018.02.037, 2018.

Swetnam, R. D. and Korenko, J.: Can computer game landscapes target new audiences for landscape quality assessment?, Appl. Geogr., 113, 102102, https://doi.org/10.1016/j.apgeog.2019.102102, 2019.

Swetnam, R. D., Harrison-Curran, S. K., and Smith, G. R.: Quantifying visual landscape quality in rural Wales: A GIS-enabled method for extensive monitoring of a valued cultural ecosystem service, Ecosyst. Serv., 26, 451-464, https://doi.org/10.1016/j.ecoser.2016.11.004, 2017.

Tebbs, E. J., Rowland, C. S., Smart, S. M., Maskell, L. C., and Norton, L. R.: Regional-scale high spatial resolution mapping of aboveground net primary productivity (ANPP) from field survey and Landsat data: a case study for the country of Wales, Remote Sens.-Basel, 9, 801, https://doi.org/10.3390/rs9080801, 2017.

UKBMS: Methods for recording butterfly transects, available at: https://ukbms.org/methods (last access: 13 August 2021), 2020.

Welsh Government: Glastir, available at: https://gov.wales/glastir (last access: 4 November 2020), 2020.

Whitton, B., John, D., Johnson, L., Boulton, P., Kelly, M., and Haworth, E.: A Coded List of Freshwater Algae of the British Isles, LOIS publication number 222, Institute of Hydrology, Wallingford, 1998.

Williams, P., Biggs, J., Dodds, L., Whitfield, M., Corfield, A., and Fox, G.: Biological techniques of still water quality assessment. Phase 1 Scoping Study, Environment Agency, Bristol, 1996.

Wood, C. M. and Bunce, R. G. H.: Survey of the terrestrial habitats and vegetation of Shetland, 1974 - a framework for longterm ecological monitoring, Earth Syst. Sci. Data, 8, 89-103, https://doi.org/10.5194/essd-8-89-2016, 2016.

Wood, C. M., Smart, S. M., Bunce, R. G. H., Norton, L. R., Maskell, L. C., Howard, D. C., Scott, W. A., and Henrys, P. A.: Longterm vegetation monitoring in Great Britain - the Countryside Survey 1978-2007 and beyond, Earth Syst. Sci. Data, 9, 445459, https://doi.org/10.5194/essd-9-445-2017, 2017.

Wood, C. M., Bunce, R. G. H., Norton, L. R., Maskell, L. C., Smart, S. M., Scott, W. A., Henrys, P. A., Howard, D. C., Wright, S. M., Brown, M. J., Scott, R. J., Stuart, R. C., and Watkins, J. W.: Ecological landscape elements: long-term monitoring in Great Britain, the Countryside Survey 1978-2007 and beyond, Earth Syst. Sci. Data, 10, 745-763, https://doi.org/10.5194/essd10-745-2018, 2018a.

Wood, C. M., Bunce, R. G. H., Norton, L. R., Maskell, L. C., Smart, S. M., Scott, W. A., Henrys, P. A., Howard, D. C., Wright, S. M., Brown, M. J., Scott, R. J., Stuart, R. C., and Watkins, J. W.: Ecological landscape elements: long-term monitoring in Great Britain, the Countryside Survey 1978-2007 and beyond, Earth Syst. Sci. Data, 10, 745-763, https://doi.org/10.5194/essd10-745-2018, 2018b. 